\title{
COVID-19 pandemic risk and probability of loan default: evidence from marketplace lending market
}

\author{
Asror Nigmonov ${ }^{1 *}$ (D) and Syed Shams ${ }^{2}$
}

\author{
${ }^{*}$ Correspondence: \\ a.nigmonov@unsw.edu.au \\ 1 University of New South \\ Wales, Sydney, Australia \\ Full list of author information \\ is available at the end of the \\ article
}

\begin{abstract}
As the COVID-19 pandemic adversely affects the financial markets, a better understanding of the lending dynamics of a successful marketplace is necessary under the conditions of financial distress. Using the loan book database of Mintos (Latvia) and employing logit regression method, we provide evidence of the pandemic-induced exposure to default risk in the marketplace lending market. Our analysis indicates that the probability of default increases from 0.056 in the pre-pandemic period to 0.079 in the post-pandemic period. COVID-19 pandemic has a significant impact on default risk during May and June of 2020. We also find that the magnitude of the impact of COVID19 risk is higher for borrowers with lower credit ratings and in countries with low levels of FinTech adoption. Our main findings are robust to sample selection bias allowing for a better understanding of and quantifying risks related to FinTech loans during the pandemic and periods of overall economic distress.
\end{abstract}

Keywords: Peer-to-peer lending, COVID-19, Coronavirus, Default risk, Marketplace lending, Pandemic, FinTech, Shadow banking

JEL Classification: E31, E43, G29, G14, O16

\section{Introduction}

Diversification of risk to investors has always been the main reason and rationale behind the existence of banks (Diamond 1984). However, after the global financial crisis of 2007-2008, banks set higher standards of lending due to greater regulations. Low returns on public markets lured investors into alternative forms of investments. COVID-19 crisis could further shift investors' preferences towards non-traditional markets, which are less liquid and transparent (Sindreu 2020). This might allow a new generation of nonbanks to come of age and transform shadow banking (banking by non-banks) within the broader development of the FinTech industry. One of those businesses is marketplace lending platforms that manage to diversify risk while not holding borrower loans in their balance sheets. This method of diversification tends to protect them against borrower defaults and maintain the required level of liquidity (Cumming and Hornuf 2018). party material in this article are included in the article's Creative Commons licence, unless indicated otherwise in a credit line to the material. If material is not included in the article's Creative Commons licence and your intended use is not permitted by statutory regulation or exceeds the permitted use, you will need to obtain permission directly from the copyright holder. To view a copy of this licence, visit http:// creativecommons.org/licenses/by/4.0/. 
During the last decade, the marketplace lending industry expanded outside stringent government regulations and more than doubled in size in China, the US, and the UK between 2010 and 2014 (Aveni et al. 2015). The rise of the marketplace lending market is often attributed to the stringent regulation of traditional bank lending after the global financial crisis, while the central cause of the crisis was growing credit default risk because of information asymmetry (Emekter et al. 2015). At their early stages, marketplace lending platforms essentially took a 'passive' role in their borrower assessment and loan provision. Individual investors mostly made investment decisions based on 'soft' information provided by the borrowers (Balyuk and Davydenko 2019). When the loan volumes grew larger, platforms automated investment decisions, developed individual scoring systems and algorithms distinct from banks or credit bureaus (Iyer et al. 2016; Jagtiani and Lemieux 2017). These changes transformed the lending decisions from investors to platforms and made them more similar to ordinary banks (Balyuk and Davydenko 2019; Ryan and Zhu 2018). By getting more involved in investing decisions, marketplace lending platforms should constantly improve their risk assessment for avoiding unsustainable losses (Flögel and Beckamp 2020).

The global pandemic of novel coronavirus (COVID-19) triggered extreme government measures worldwide that restricted economic activity. In the absence of a vaccine or treatment, lockdown and social distancing measures were broadly perceived as an effective way to contain the disease. These measures had a systematic impact on the financial sector and the broader economy via business closures and disruptions of the global value chain. Ongoing economic downturn as a result of the COVID-19 pandemic increases the likelihood of unsustainable losses by the marketplace lending industry. Losses in the industry are expected to increase substantially over a major economic downturn, which can quickly exhaust investor funds (Bolt et al. 2012). Unlike prior infectious disease pandemics, the COVID-19 pandemic has a vast global economic and financial impact, allowing us to study this emerging issue in a large cross-country context.

The literature related to the COVID-19 pandemic is currently in its infancy, primarily due to its ongoing and rapidly evolving nature. Nevertheless, several studies have reported the early impact of COVID-19 on banks, financial markets and the economy overall (Agosto and Giudici 2020; Auer et al. 2020; Baldwin and Di Mauro 2020; Civelek and Xiarewana 2020; Demirguc-Kunt et al. 2020a, b; Stiller and Zink 2020; Wu and Olson 2020; Bose et al. 2021). A limited number of studies examined the impact of the COVID-19 pandemic on FinTech adoption and its popularity (Fu and Mishra 2020; Najaf et al. 2021). However, no prior studies, to our knowledge, explore the implications of the COVID-19 pandemic for the risk levels and defaults in non-bank or FinTech lending markets.

To investigate the effects of COVID-19 risk on FinTech lending, we examine the likelihood of loan default due to the COVID-19 pandemic among marketplace lending loans. The central question of this study is: How does the COVID-19 risk affect marketplace lending market defaults? We use the loan book dataset of Mintos (Latvia) marketplace lending platform in conjunction with the borrower- and country-specific factors. Our logistic regression estimates indicate that the COVID-19 pandemic risk increases the likelihood of loan default. Specifically, the odds ratio indicates a 2.5 times higher likelihood of default in the post-pandemic period than the pre-pandemic period. We also 
document that marginal changes in the probability of default are $0.39-0.63 \%$ lower among the countries with high FinTech adoption than countries with low FinTech adoption. Our analysis further shows that the impact of COVID-19 risk was not solidly reflected in loan defaults until April 2020. Loans with lower ratings are also more likely to default, with a $2.30 \%$ higher likelihood of default in the post-pandemic period than the pre-pandemic period.

Our paper contributes to the existing literature in several ways. First, we provide early evidence that COVID-19 pandemic risk significantly increases the likelihood of loan default. Second, we evaluate the monthly impact of COVID-19 pandemic risk on default risk and provide evidence that the likelihood of loan defaults is highest in the month of May and June. Third, we find that borrowers credit ratings and country-level FinTech adoption act as a cushion to prevent the likelihood of loan default. Overall, we provide a unique insight into how the COVID-19 pandemic impacts the likelihood of loan default in particular. In this regard, the findings of our study might have important implications for both marketplace lending investors, platforms and policymakers.

Most of the marketplace lending platforms are currently revising their main security tool against the financial hardship, 'provision fund. Platforms now withhold up to $50 \%$ of investor interest income to contribute to a 'provisional fund' (RateSetter 2020). This type of extreme measure may be helpful to solve short-term liquidity problems but drives away yield-hungry investors in the long term. Our study allows for quantifying risks and analysing risk factors in the marketplace lending market during financial distress. Thus, it fills the gap in the existing literature by developing a cross country model tested via econometric analysis. The findings of this study in terms of COVID-19 risk can guide platform management in overcoming or controlling various risk factors. The model used in our study by including both loan and economy specific variables might serve as a framework of risk management in marketplace lending platforms. By extending the modelling and findings of the current study marketplace, lending platforms and investors can improve their risk management models. Marketplace lending platforms can improve their security mechanisms, and investors can adjust their loan portfolios.

The rest of this paper is organised as follows. Second section describes the background of the topic, and third section explains the methodology and data. Fourth section discusses the empirical findings of the study. Fifth section is the discussion and conclusion.

\section{Background of the topic}

Several studies explore the impact of earlier pandemics on the financial sector and the economy overall. Pandemics are historically known to have a considerable economic cost attached to them that can significantly influence the financial systems (Haacker 2004; Santaeulalia-Llopis 2008; Yach et al. 2006). Goodell (2020) emphasises that the COVID-19 pandemic can be paralleled to other survivable disasters, including earthquakes, volcanic eruptions, air disasters, and terrorist attacks. COVID-19, as a survivable global pandemic, is projected to have a long-term imprint on firm financing and the cost of capital (Goodell 2020). Elnahas et al. (2018) debated that organisations located in a disaster-prone area tend to be less levered. For that reason, COVID-19 is estimated to bring together less levered principal structures. 
The influence of a pandemic on the economy at the global level is undervalued. As a result, financial prudence tends to underinvest in preparation for it, which became prominent when the spending behaviours changed globally after the outbreak of the COVID-19 pandemic. Leoni (2013) studied the spread of the Human Immunodeficiency Virus in developing countries and indicated its association with deposit withdrawals. Lagoarde-Segot and Leoni (2013) forecasted that pandemics could result in a downfall in the banking industry. Moreover, pandemic affects advancing loans to the poor as investing groups, and banks get overstretched by the economic recession (Skoufias 2003). Therefore, the COVID-19 pandemic is anticipated to influence the financial sector similarly with insolvency spikes and a disproportionate reduction in the loans to the poor.

COVID-19 pandemic is distinct from earlier pandemics because of its widespread global impact on people's health, mobility, and social welfare. The ongoing and expected decline in business revenues and household income is likely to be massive (Sadang 2020). According to the Organisation for Economic Co-operation and Development (OECD) (2020), sales volume has dropped significantly, and companies facing unsolvable financial difficulties to pay their suppliers, employees, lenders, and investors, which leads to liquidity problems. Recent studies documented the negative impact of COVID19 on exchange rate returns, stock market volatility, firm values (Ali et al. 2020; Dawson 2020; Iyke 2020; Shen et al. 2020).

Several of the latest studies specifically addressed the role of new financial technologies to eliminate the after-effects of the COVID-19 crisis. Auer et al. (2020) state that the developments in finance could speed up the shift toward digital payments. Fu and Mishra (2020) indicate that during the COVID-19 pandemic, daily downloads of finance mobile applications increased by $24-32 \%$ among the sample of 74 countries globally. This transformation could open a divide in access to payment instruments, which could negatively impact unbanked and older consumers. The pandemic may also amplify calls to defend the role of cash and central bank digital currencies. Cecchetti and Schoenholtz (2020) emphasise the importance of an extraordinary disclosure mechanism and stress tests for restoring investor confidence in the financial sector after the COVID-19 crisis. Sahay et al. (2020) point to the positive impact of digital finance on increasing welfare and reducing inequalities in financial access following the COVID-19 crisis. They underscore that digital financial services are faster, more efficient, and typically cheaper than traditional financial services and, therefore, increasingly reaching lower-income households and small- and medium-sized enterprises (SMEs).

Agosto and Giudici (2020) perform contagion monitoring for establishing the impact of COVID-19 on digital finance in the first country affected by COVID-19, China. Agosto and Giudici (2020) highlight that in the first week of February, the cases of COVID19 accelerated the contagion and the Shanghai Stock Exchange (SSE) composite index plummeted. They observe a negative but weak correlation between SSE returns and reported COVID-19 cases at a later stage of the epidemic. Demirguc-Kunt et al. (2020a) analyse bank stock prices worldwide to assess the impact of the COVID-19 pandemic on the banking sector. They highlight that bank stocks underperform their domestic markets and other non-bank financial firms during the COVID-19 crisis. Banks are expected to play a countercyclical lending role that put them under significant stress. At the same time, banks interact with the rest of the global financial system via multiple linkage types 
which particularly increases the risk of distress during the contagion. As presented by Avdjiev et al. (2019), multidimensional interlinkages between economic agents create the multi-layered network where the exposure to credit risk transfers to the non-bank private financial sector.

Li et al. (2021) show that the COVID-19 crisis adversely affects banking stability and makes it more prone to risk-taking. They also highlight that the COVID-19 outbreak and government capital injections harm the efficiency gain from shadow banking. Najaf et al. (2021) find a significant increase in FinTech loans among the US peer-to-peer lending market. However, they highlight that this increase was accompanied by a hike in unverified loans, loan terms and interest rates. Sahay et al. (2020) indicate that due to weak demand during the COVID-19 pandemic, funding conditions tighten, and transactions drop sharply. These changes in market conditions hit FinTech companies hard, especially the smaller ones and those with thinner buffers (Sahay et al. 2020).

Alternative lending markets, such as marketplace lending, mainly serve small businesses and low-income households. They are prone to use marketplace platforms as a 'last resort' when they lack funds and exhaust all of their available debt capacity (Walthoff-Borm et al. 2018). Moreover, marketplace lending markets tend to reduce costs and improve user experience at the expense of inaccurate credit risk measurements (Giudici et al. 2020). Accordingly, our study expects that the current pandemic negatively affects the risk incurred by marketplace lending platforms by creating a 'bank-run' type scenario, as projected in Peckham (2013). On the other hand, governments implemented several COVID-19 support programs to ease the financial hurdles of small enterprises and low-income households. These measures are intended to mitigate the economy's downturn and safeguard against borrower delinquencies (Civelek and Xiarewana 2020). Gordon and Jones (2020) forecasted loan delinquency rates under the COVID-19 pandemic in three scenarios depending on the policy interventions. They predict an increase in the US loan delinquency rates from 2.3\% in 2019 to $3.1 \%$ in 2021 under the baseline scenario (intermediate projection). Simultaneously, these increases might vary between 2.6 and 3.5\%, depending on the policy intervention measures (Gordon and Jones 2020).

The early impact of the current pandemic on the marketplace lending market is not yet documented in empirical studies. Based on the arguments mentioned above, we predict that the COVID-19 pandemic has a negative impact on loan defaults in the marketplace lending market. At the same time, we expect the magnitude of the impact to be higher than the banking sector delinquencies. Moreover, we also expect that the pandemic has a varying impact within the marketplace lending market depending on loan ratings. The current study aims to shed more light on the early impact of COVID-19 risk on marketplace lending markets and broaden the understanding of the current market conditions.

\section{Methodology and data}

\section{Regression models}

We employ logit regression analysis as per Eq. (1) to measure the impact of COVID-19 pandemic risk on the likelihood of loan default risk. Equation (1) uses a binary dependent variable with a number of the country- and borrower-specific control variables. Logit regression estimates the determinants of the likelihood of loan default $\left(\theta_{i}\right)$. 


$$
\theta_{i}=\operatorname{Pr}\left(\mathrm{D}_{\mathrm{i}}=1 \mid \text { Observed variables }\right)=\operatorname{Pr}\left(\alpha+\beta_{\mathrm{P}} \mathrm{P}+\beta_{\mathrm{E}} \mathrm{X}_{\mathrm{i}}^{\mathrm{E}}+\beta_{\mathrm{B}} \mathrm{X}_{\mathrm{i}}^{\mathrm{B}}+\beta_{\mathrm{L}} \mathrm{L}+\varepsilon_{\mathrm{i}}\right)
$$

$D_{i}$ is a binary variable representing the loan status (DEFAULT) of loan $i$ that takes the value of 1 if the loan is overdue, defaulted or buyback ${ }^{1}$ and 0 otherwise (current or repaid). $\beta_{P} P$ is the variable representing the COVID-19 pandemic risk. Following the early studies of the COVID-19 pandemic (Iyke 2020; Bose et al. 2021; Nigmonov and Daradkeh 2020; Okorie and Lin 2021), we use three proxies to represent the pandemic risk: (1) a dummy variable that equals 1 for the period no later than March 11, 2020, when the World Health Organization (WHO) declared COVID-19 as the pandemic and 0 otherwise; (2) the total daily number of country-level reported cases of COVID-19 per million population and (3) the total daily number of reported COVID-19 related deaths per million population at the country level. There is no evidence from existing studies regarding the direction of the expected impact of the pandemic risk on loan defaults. However, several prior studies reported higher levels of non-performing loans (NPL) and risk exposure during the previous crises faced by financial sectors worldwide (Ari et al. 2020; Avdjiev et al. 2019; Laeven and Valencia 2013). $\beta_{E} X_{i}^{E}$ represents the vector of economy-specific control variables. ${ }^{2}$ We support the inclusion of economy-specific variables with existing literature on both traditional financial institutions (Ali and Daly 2010; Bofondi and Ropele 2011; Greenwald and Stiglitz 1993; Kou et al. 2021; Stiglitz and Weiss 1992) and alternative financial markets (Dushnitsky et al. 2016; Mollick 2014; Ning et al. 2015; Wang et al. 2021). The existing studies on marketplace lending extensively use borrower and loan characteristics in estimating loan defaults (Cai et al. 2016; Galema 2020; Li et al. 2018; Nigmonov et al. 2021; Serrano-Cinca et al. 2015; Wei and Lin 2017). Thus, we use the vector of borrower-specific control variables denoted as $\beta_{B} X_{i}^{B}$ in Eq. (1). We also note that marketplace lending markets are characterized by a high interdependence between loans and issuing countries. Giudici et al. (2020) suggest using borrowing companies as a vertex of correlation network for representing this interdependence and interconnections. Therefore, we use $\beta_{L} L$, the vector of dummy variables, for 'loan originator' individual effects ${ }^{3}$ that in turn represent network centrality of loans.

\section{Data and sampling}

In this study, we use the loan book database of the Mintos marketplace lending platform. The scope of this study covers the loans issued across the multiple countries of the European Union (EU). The marketplace lending market in continental Europe is experiencing high rapid growth. Countries in continental Europe have similar regulations and represent an excellent opportunity for analysing the current tendencies in marketplace lending markets.

Mintos is a marketplace for loans issued by non-banking financial institutions or the shadow banking sector. The company's marketplace platform simultaneously lists loans from multiple lending companies, so-called 'loan originators'. Most loans are with a buyback guarantee, a credit enhancement given by the 'loan originator' to the investor for a

\footnotetext{
${ }^{1}$ Refer to Table 2 for the description and breakdown of loans.

2 "Appendix 1" describes all the variables used in the study.

3 Please refer to "Appendix 2" for the breakdown of loans by loan originators.
} 
Table 1 Breakdown of loans by rating in pre- and post-pandemic period

\begin{tabular}{|c|c|c|c|c|c|}
\hline \multirow[t]{2}{*}{ Rating } & \multicolumn{2}{|c|}{ Pre-pandemic } & \multirow[t]{2}{*}{ Rating } & \multicolumn{2}{|c|}{ Post-pandemic } \\
\hline & $\mathbf{N}$ & $\%$ & & $\mathrm{~N}$ & $\%$ \\
\hline$A$ & 3073 & 0.57 & $A$ & 857 & 0.31 \\
\hline A- & 112,652 & 20.91 & A- & 65,114 & 23.57 \\
\hline$B+$ & 194,856 & 36.17 & B & 134,486 & 48.69 \\
\hline B & 17,508 & 3.25 & $B+$ & 4565 & 1.65 \\
\hline$B-$ & 206,652 & 38.36 & $B-$ & 70,310 & 25.45 \\
\hline$C+$ & 3489 & 0.65 & $C+$ & 898 & 0.33 \\
\hline D & 426 & 0.08 & $\mathrm{D}$ & - & - \\
\hline Total & 538,656 & 100.00 & Total & 276,230 & 100.00 \\
\hline
\end{tabular}

Total values are in bold

particular loan. If the loan is over 60 days late, the lending company is obligated to buy back the investment at nominal value plus accrued interest. During the market turmoil, loan originators struggle to oblige with buyback guarantees. Therefore, we classify loans that are more than 30 days late or buyback as defaults. Loan originators listed in Mintos are based in 30 countries, including $10 \mathrm{EU}$ countries. Investors in the marketplace are from 66 countries, though Mintos does not disclose information about the investor categories and origination.

As the scope of our study is limited to EU countries, we restrict the database to loans issued by loan originators in EU countries. The countries included in the database are Bulgaria, Czech Republic, Denmark, Estonia, Finland, Latvia, Lithuania, Poland, Spain, Romania and the United Kingdom. These countries are similar in terms of their regulatory framework and business environment. At the same time, the inclusion of countries outside the EU would distort our analysis by complicating the comparisons and reducing the data quality. We provide the distribution of loans by loan originators in Table 12 of "Appendix 2". During the pandemic period, Mintos discontinued some risky loans and put more stringent requirements for borrowers. This is evident from Table 12, where the number of loans and loan originators decreased during the pandemic. We address the heterogeneity of the database regarding loan originators by including the loan originator individual effects in the regression models.

Table 1 provides the breakdown of loans by the borrower ratings, indicating a sharp decline in lower-rated loans. We observe that the share of loans classified as ' $\mathrm{B}$ ' and ' $\mathrm{B}-$ ' decreased from $3.25 \%$ and $38.36 \%$ in the pre-pandemic period to $1.65 \%$ and $25.45 \%$ in the post-pandemic period, respectively. We mitigate for different risk levels of borrowers by analysing the impact of COVID-19 risk in the breakdown of loan ratings.

The database used in this study consists of all the loans issued by Mintos loan originators based in the EU from January 2020 to June 2020. We combine each of the loans recorded in the database with the country-specific economic variables and variables representing COVID-19 risk $^{4}$ as defined in Eq. (1). The updated database consists of 13 variables with 814,872 loan listing observations. Table 11 in "Appendix 1" describes all variables used in this study.

\footnotetext{
${ }^{4}$ We match these variables based on closing date or last payment date of each loan.
} 
Table 2 Breakdown of loans by loan status and current resolution

\begin{tabular}{|c|c|c|c|}
\hline Loan status & $\mathbf{N}$ & $\%$ & Cumulative \% \\
\hline \multicolumn{4}{|c|}{ Panel A: Breakdown of loans by loan status } \\
\hline Current & 182,732 & 22.43 & 22.43 \\
\hline Default & 2 & 0.00 & 22.43 \\
\hline Finished as scheduled & 72,916 & 8.95 & 31.38 \\
\hline Finished prematurely & 453,359 & 55.65 & 87.03 \\
\hline Grace Period & 12,766 & 1.57 & 88.60 \\
\hline Late $1-15$ & 23,078 & 2.83 & 91.43 \\
\hline Late 16-30 & 22,378 & 2.75 & 94.18 \\
\hline Late $31-60$ & 47,365 & 5.81 & 100.00 \\
\hline Late 60+ & 37 & 0.00 & 100.00 \\
\hline \multirow[t]{2}{*}{ Total } & 814,633 & 100.00 & \\
\hline & & $N$ & $\%$ \\
\hline \multicolumn{4}{|c|}{ Panel B: Breakdown of loans by current resolution } \\
\hline \multicolumn{4}{|c|}{ January } \\
\hline Unresolved & & 39,056 & 16.63 \\
\hline Resolved & & 195,809 & 83.37 \\
\hline Total & & 234,865 & 100.00 \\
\hline \multicolumn{4}{|l|}{ February } \\
\hline Unresolved & & 55,814 & 25.63 \\
\hline Resolved & & 161,959 & 74.37 \\
\hline Total & & 217,773 & 100.00 \\
\hline \multicolumn{4}{|l|}{ March } \\
\hline Unresolved & & 68,796 & 40.10 \\
\hline Resolved & & 102,764 & 59.90 \\
\hline Total & & 171,560 & 100.00 \\
\hline \multicolumn{4}{|l|}{ April } \\
\hline Unresolved & & 36,509 & 45.69 \\
\hline Resolved & & 43,401 & 54.31 \\
\hline Total & & 79,910 & 100.00 \\
\hline \multicolumn{4}{|l|}{ May } \\
\hline Unresolved & & 72,661 & 76.90 \\
\hline Resolved & & 21,823 & 23.10 \\
\hline Total & & 94,484 & 100.00 \\
\hline \multicolumn{4}{|l|}{ June } \\
\hline Unresolved & & 15,759 & 96.72 \\
\hline Resolved & & 535 & 3.28 \\
\hline Total & & 16,294 & 100.00 \\
\hline \multicolumn{4}{|l|}{ All loans } \\
\hline Unresolved & & 288,595 & 35.42 \\
\hline Resolved & & 526,291 & 64.58 \\
\hline Total & & 814,886 & 100.00 \\
\hline
\end{tabular}

Total values are in bold

Table provides the breakdown of loans by their respective statuses. Panel A classifies all loans by the loan status. Panel B provides the breakdown of loans to resolved and unresolved loan categories for each month of 2020 and for the whole database

Panel A of Table 2 provides the breakdown of loans by loan status for the database used in the study. Loans are classified as Current, Default, Finished (as scheduled or prematurely), Grace Period, and Late loans. However, loans classified as 'Finished' might 
Table 3 Descriptive statistics

\begin{tabular}{|c|c|c|c|c|c|c|c|c|}
\hline & \multicolumn{3}{|c|}{ Pre-pandemic } & \multicolumn{3}{|c|}{ Post-pandemic } & \multicolumn{2}{|c|}{ Two-sample t-test } \\
\hline & $\mathrm{N}$ & Mean & St. dev. & $\mathbf{N}$ & Mean & St. dev. & Mean diff. & t-stat \\
\hline DEFAULT & 538,656 & 0.110 & 0.312 & 276,230 & 0.074 & 0.262 & $0.036^{* * *}$ & (51.33) \\
\hline PANDEM_DUM & 538,656 & 0.000 & 0.000 & 276,230 & 1.000 & 0.000 & N/A & N/A \\
\hline DAILY_CASES & 226,980 & 0.598 & 2.121 & 276,187 & 24.348 & 40.597 & $-23.750^{* * *}$ & $(-278.40)$ \\
\hline DAILY_DEATHS & 226,980 & 0.005 & 0.044 & 276,187 & 2.053 & 6.059 & $-2.049^{* * *}$ & $(-161.09)$ \\
\hline MARKET_VOL & 538,656 & -0.003 & 0.631 & 276,230 & 0.003 & 1.293 & $-0.005^{* *}$ & $(-2.59)$ \\
\hline ESI & 538,656 & 99.854 & 2.800 & 276,230 & 75.675 & 17.997 & $24.180^{* * *}$ & $(963.56)$ \\
\hline AAR & 538,656 & 13.066 & 3.284 & 276,230 & 13.289 & 1.960 & $-0.223^{* * *}$ & $(-32.84)$ \\
\hline UNEMPL & 538,656 & 6.772 & 4.128 & 276,230 & 8.426 & 4.987 & $-1.653^{* * *}$ & $(-159.19)$ \\
\hline EXT_SCHED & 538,656 & 0.613 & 0.487 & 276,230 & 0.760 & 0.427 & $-0.146^{* * *}$ & $(-133.74)$ \\
\hline INTEREST & 538,656 & 11.607 & 2.853 & 276,230 & 13.931 & 3.301 & $-2.324^{* * *}$ & $(-329.71)$ \\
\hline LOAN_TERM & 538,656 & 6.774 & 15.553 & 276,230 & 5.086 & 12.864 & $1.688^{* * *}$ & (49.09) \\
\hline AMOUNT & 538,656 & 632.093 & 1134.417 & 276,230 & 546.145 & 968.904 & $85.950^{* * *}$ & (33.97) \\
\hline COLLATERAL & 538,656 & 1.092 & 0.289 & 276,230 & 1.111 & 0.314 & $-0.019^{* * *}$ & $(-27.43)$ \\
\hline
\end{tabular}

T-statistics in parentheses. ${ }^{* * *},{ }^{*}$, and ${ }^{*}$ represent statistical significance at the $1 \%, 5 \%$ and $10 \%$ levels, respectively. Variable definitions are provided in "Appendix 1"

be the 'buyback' loans, which we classify as defaults ${ }^{5}$ in the regression models. We provide the complete breakdown of resolved and unresolved loans for the first six months of 2020 in Panel B of Table 2. Around 65\% of our database consists of loans with clear ending resolution (resolved loans), as reported in the last rows of Table 2. The share of resolved loans shrinks from around $83 \%$ in January to $3 \%$ in June 2020 . We mitigate the high representation of loans with a clear ending resolution in the robustness tests section of this paper.

We report the descriptive statistics in the breakdown of pre and post-pandemic periods in Table 3. There is a statistically significant difference in loan default probabilities between these two periods. Mintos policy during the pandemic period that discontinued loans from risky borrowers lead to massive reductions in the number of issued loans and risk level of the overall loan portfolio. Mintos also complied with government regulations providing more concessions for borrowers. It is reflected in the share of loans with extended schedule (EXT_SCHED), which significantly increased during the pandemic period. We test for the possibility of default loans being bailed out by the governments in the respective robustness tests section of this paper. Table 3 also indicates significant changes in economy specific indicators and loan characteristics for which we control in all regression models.

We report a correlation matrix in Table 4 for the variables employed in the empirical analysis. The majority of the variables have a low level of statistically significant correlation with one another, as reflected in small correlation coefficients. We observe the high correlation coefficients between variables that are not used in the same model. For example, the correlation coefficient between DAILY_CASES and DAILY_DEATHS is 0.7354 , indicating a strong positive correlation. We use these two variables as the different proxies of the same indicator.

\footnotetext{
${ }^{5}$ We classify loans that are more than 30 days late as 'default' loans.
} 
Table 4 Correlation matrix

\begin{tabular}{|c|c|c|c|c|c|c|c|}
\hline & DEFAULT & $\begin{array}{l}\text { PANDEM_ } \\
\text { DUM }\end{array}$ & $\begin{array}{l}\text { DAILY } \\
\text { CASES }\end{array}$ & $\begin{array}{l}\text { DAILY } \\
\text { DEATHS }\end{array}$ & $\begin{array}{l}\text { MARKET_ } \\
\text { VOL }\end{array}$ & ESI & AAR \\
\hline DEFAULT & 1.0000 & & & & & & \\
\hline $\begin{array}{l}\text { PANDEM_ } \\
\text { DUM }\end{array}$ & $-0.0568^{* * *}$ & 1.0000 & & & & & \\
\hline $\begin{array}{l}\text { DAILY } \\
\text { CASES }\end{array}$ & $0.0778^{* * *}$ & $0.3653^{* * *}$ & 1.0000 & & & & \\
\hline $\begin{array}{l}\text { DAILY } \\
\text { DEATHS }\end{array}$ & $0.0316^{* * *}$ & $0.2215^{* * *}$ & $0.7354^{* * *}$ & 1.0000 & & & \\
\hline $\begin{array}{l}\text { MARKET_ } \\
\text { VOL }\end{array}$ & 0.0004 & $0.0029^{* *}$ & 0.0020 & 0.0001 & 1.0000 & & \\
\hline ESI & $0.1338^{* * *}$ & $-0.7298^{* * *}$ & $-0.0904^{* * *}$ & $-0.0840^{* * *}$ & $-0.0023^{*}$ & 1.0000 & \\
\hline AAR & $-0.1629^{* * *}$ & $0.0364^{* * *}$ & $-0.0790^{* * *}$ & $-0.0119^{* * *}$ & 0.0010 & $-0.1446^{* * *}$ & 1.0000 \\
\hline UNEMPL & $0.0693^{* * *}$ & $0.1737^{* * *}$ & $0.3331^{* * *}$ & $0.2464^{* * *}$ & 0.0001 & $0.0558^{* * *}$ & $-0.6595^{* * *}$ \\
\hline EXT_SCHED & $0.0785^{* * *}$ & $0.1466^{* * *}$ & $0.0780^{* * *}$ & $0.0441^{* * *}$ & 0.0000 & $-0.0789^{* * *}$ & $0.0402^{* * *}$ \\
\hline INTEREST & $-0.0847^{* * *}$ & $0.3431^{* * *}$ & $0.0114^{* * *}$ & $-0.0212^{* * *}$ & 0.0018 & $-0.3521^{* * *}$ & $0.2854^{* * *}$ \\
\hline LOANTERM & $-0.0389^{* * *}$ & $-0.0543^{* * *}$ & $-0.0976^{* * *}$ & $-0.0664^{* * *}$ & -0.0007 & $0.0666^{* * *}$ & $0.1725^{* * *}$ \\
\hline AMOUNT & $0.0413^{* * *}$ & $-0.0376^{* * *}$ & $-0.0651^{* * *}$ & $-0.0459^{* * *}$ & -0.0007 & $-0.0228^{* * *}$ & $0.1177^{* * *}$ \\
\hline RATING & $-0.0782^{* * *}$ & $-0.1221^{* * *}$ & $-0.0799^{* * *}$ & $-0.0582^{* * *}$ & 0.0017 & $-0.0301^{* * *}$ & $0.2552^{* * *}$ \\
\hline \multirow[t]{2}{*}{ LOANTYPE } & $0.0378^{* * *}$ & $-0.0116^{* * *}$ & $0.1075^{* * *}$ & $0.0722^{* * *}$ & -0.0000 & $-0.0827^{* * *}$ & $-0.1373^{* * *}$ \\
\hline & UNEMPL & EXT_SCHED & INTEREST & TERM & AMOUNT & RATING & LOANTYPE \\
\hline UNEMPL & 1.0000 & & & & & & \\
\hline EXT_SCHED & $0.0910^{* * *}$ & 1.0000 & & & & & \\
\hline INTEREST & $-0.2974^{* * *}$ & $0.4133^{* * *}$ & 1.0000 & & & & \\
\hline LOANTERM & $-0.2311^{* * *}$ & $-0.3037^{* * *}$ & $-0.0342^{* * *}$ & 1.0000 & & & \\
\hline AMOUNT & $-0.1922^{* * *}$ & $-0.0624^{* * *}$ & $-0.0032^{* *}$ & $0.0754^{* * *}$ & 1.0000 & & \\
\hline RATING & $-0.3178^{* * *}$ & $0.3536^{* * *}$ & $0.5418^{* * *}$ & $-0.2778^{* * *}$ & $0.0592^{* * *}$ & 1.0000 & \\
\hline LOANTYPE & $0.0561^{* * *}$ & $0.1656^{* * *}$ & $0.3395^{* * *}$ & $-0.2680^{* * *}$ & $0.0093^{* * *}$ & $0.5444^{* * *}$ & 1.0000 \\
\hline
\end{tabular}

Table reports Pearson correlations. High correlations are in boldface. ${ }^{* * *}, * *$, and ${ }^{*}$ represent statistical significance at the $1 \%$, $5 \%$ and $10 \%$ levels, respectively (for two-tailed $p$ values)

\section{Empirical analysis}

Baseline regression

Table 5 provides the results of the regression models with the status of loans as the dependent variable. The results show a significant impact of COVID-19 pandemicrelated risk on the likelihood of loan defaults. All three proxies of the pandemic risk (PANDEMIC_DUMMY, DAILY_CASES and DAILY_DEATHS) generate significant and positive coefficients which are consistent across Models (1), (2) and (3). Specifically, the increase in COVID-19 related deaths tends to increase the likelihood of default significantly ( $\beta=0.037)$. On the other hand, the number of daily reported COVID-19 cases tend to have a smaller impact on the likelihood of default with a relatively lower magnitude of a coefficient $(\beta=0.004)$. To quantify the effect of COVID-19 risk on loan status, we estimate pre- and post-pandemic default probabilities while holding all other variables constant in their mean values. ${ }^{6}$ Based on the baseline regression model results, the probability of default increased from 0.056 (pre-pandemic) to 0.079 (post-pandemic).

\footnotetext{
${ }^{6}$ We perform respective transformations of the marginal impact of coefficients based on logistic function.
} 
Table 5 COVID-19 risk and the likelihood of loan default

\begin{tabular}{|c|c|c|c|}
\hline Variables & $\begin{array}{l}\text { DV = DEFAULT } \\
\text { (1) }\end{array}$ & $\begin{array}{l}\text { DV = DEFAULT } \\
\text { (2) }\end{array}$ & $\begin{array}{l}\text { DV = DEFAULT } \\
\text { (3) }\end{array}$ \\
\hline PANDEMIC_DUMMY & $\begin{array}{l}0.533^{* * *} \\
(0.006)\end{array}$ & & \\
\hline DAILY_CASES & & $\begin{array}{l}0.004^{* * *} \\
(0.000)\end{array}$ & \\
\hline DAILY_DEATHS & & & $\begin{array}{l}0.037^{* * *} \\
(0.001)\end{array}$ \\
\hline MARKET_VOL & $\begin{array}{l}0.002 \\
(0.002)\end{array}$ & $\begin{array}{l}0.001 \\
(0.003)\end{array}$ & $\begin{array}{l}0.002 \\
(0.003)\end{array}$ \\
\hline ESI & $\begin{array}{l}0.031^{* * *} \\
(0.000)\end{array}$ & $\begin{array}{l}0.029^{* * *} \\
(0.000)\end{array}$ & $\begin{array}{l}0.030^{* * *} \\
(0.000)\end{array}$ \\
\hline AAR & $\begin{array}{l}-0.088^{* * *} \\
(0.001)\end{array}$ & $\begin{array}{l}-0.086^{* * *} \\
(0.001)\end{array}$ & $\begin{array}{l}-0.094^{* * *} \\
(0.001)\end{array}$ \\
\hline UNEMPL & $\begin{array}{l}-0.046^{* * *} \\
(0.001)\end{array}$ & $\begin{array}{l}-0.026^{* * *} \\
(0.001)\end{array}$ & $\begin{array}{l}-0.027^{* * *} \\
(0.001)\end{array}$ \\
\hline COLLATERAL & $\begin{array}{l}-1.342^{* * *} \\
(0.359)\end{array}$ & $\begin{array}{l}-1.132^{* * *} \\
(0.439)\end{array}$ & $\begin{array}{l}-1.125^{* *} \\
(0.439)\end{array}$ \\
\hline EXT_SCHED & $\begin{array}{l}0.636^{* * *} \\
(0.006)\end{array}$ & $\begin{array}{l}0.726^{* * *} \\
(0.008)\end{array}$ & $\begin{array}{l}0.729^{* * *} \\
(0.008)\end{array}$ \\
\hline INTEREST & $\begin{array}{l}-0.897^{* * *} \\
(0.012)\end{array}$ & $\begin{array}{l}0.264^{* * *} \\
(0.015)\end{array}$ & $\begin{array}{l}0.352^{* * *} \\
(0.015)\end{array}$ \\
\hline LOANTERM & $\begin{array}{l}-0.093^{* * *} \\
(0.003)\end{array}$ & $\begin{array}{l}-0.087^{* * *} \\
(0.004)\end{array}$ & $\begin{array}{l}-0.083^{* * *} \\
(0.004)\end{array}$ \\
\hline AMOUNT & $\begin{array}{l}0.192^{* * *} \\
(0.002)\end{array}$ & $\begin{array}{l}0.225^{* * *} \\
(0.003)\end{array}$ & $\begin{array}{l}0.226^{* * *} \\
(0.003)\end{array}$ \\
\hline \multicolumn{4}{|l|}{ LOAN TYPE } \\
\hline Business loan & $\begin{array}{l}0.670^{* *} \\
(0.277)\end{array}$ & $\begin{array}{l}1.342^{* * *} \\
(0.373)\end{array}$ & $\begin{array}{l}1.345^{* * *} \\
(0.374)\end{array}$ \\
\hline Car loan & $\begin{array}{l}1.399^{* * *} \\
(0.369)\end{array}$ & $\begin{array}{l}1.547^{* * *} \\
(0.470)\end{array}$ & $\begin{array}{l}1.540^{* * *} \\
(0.471)\end{array}$ \\
\hline Pawnbroking loan & $\begin{array}{l}1.694^{* * *} \\
(0.367)\end{array}$ & $\begin{array}{l}2.256^{* * *} \\
(0.469)\end{array}$ & $\begin{array}{l}2.267^{* * *} \\
(0.470)\end{array}$ \\
\hline Personal loan & $\begin{array}{l}1.239^{* * * *} \\
(0.111)\end{array}$ & $\begin{array}{l}1.551^{* * *} \\
(0.175)\end{array}$ & $\begin{array}{l}1.537^{* * *} \\
(0.176)\end{array}$ \\
\hline Short-term loan & $\begin{array}{l}0.953^{* * *} \\
(0.110)\end{array}$ & $\begin{array}{l}1.102^{* * *} \\
(0.175)\end{array}$ & $\begin{array}{l}1.093^{* * *} \\
(0.176)\end{array}$ \\
\hline Intercept & $\begin{array}{l}-2.468^{* * *} \\
(0.386)\end{array}$ & $\begin{array}{l}-5.883^{* * *} \\
(0.479)\end{array}$ & $\begin{array}{l}-6.070^{* * *} \\
(0.480)\end{array}$ \\
\hline Loan originator individual effects & Yes & Yes & Yes \\
\hline LR chi2 & $68,062.632$ & $59,563.239$ & $58,885.153$ \\
\hline Prob >chi2 & 0.000 & 0.000 & 0.000 \\
\hline Pseudo-R-squared & 0.131 & 0.175 & 0.173 \\
\hline N & 814,872 & 503,167 & 503,167 \\
\hline
\end{tabular}

Table presents the results of logit regression analysis for the likelihood of loan default (DEFAULT). Number of loans analysed: 814,872. Current or repaid: 735,387 (90.25\%). Default, late or buyback: 79,485 (9.75\%). Refer to Table 11 in "Appendix 1" for the description of variables. All model specifications employ robust standard errors in parentheses $\left({ }^{*} p<0.10\right.$, ${ }^{* *} p<0.05$, *** $p<0.01)$

\section{Additional analyses}

Another specific aspect of our sample is that it incorporates diverse countries regarding their efficiency of the credit market and FinTech development. On the other hand, these countries are similar in terms of their geographical location and operate under the EU jurisdiction. This unique aspect of our database creates an opportunity to explore the 
Table 6 COVID-19 risk and the likelihood of loan default: the role of FinTech adoption

\begin{tabular}{|c|c|c|c|}
\hline \multirow[t]{2}{*}{ Variables } & \multicolumn{3}{|c|}{$\mathrm{DV}=\mathrm{DEFAULT}$} \\
\hline & (1) & $(2)$ & (3) \\
\hline \multicolumn{4}{|l|}{ Panel A: high FinTech adoption } \\
\hline PANDEMIC_DUMMY & $\begin{array}{l}0.267^{* * *} \\
(0.007)\end{array}$ & & \\
\hline DAILY_CASES & & $\begin{array}{l}0.003^{* * *} \\
(0.000)\end{array}$ & \\
\hline DAILY_DEATHS & & & $\begin{array}{l}0.025^{* * *} \\
(0.001)\end{array}$ \\
\hline Loan originator individual effects & Yes & Yes & Yes \\
\hline Controls & Yes & Yes & Yes \\
\hline LR chi2 & $75,221.734$ & $58,608.936$ & $58,155.240$ \\
\hline Prob > chi2 & 0.000 & 0.000 & 0.000 \\
\hline Pseudo-R-squared & 0.171 & 0.191 & 0.189 \\
\hline N & 588,385 & 415,370 & 415,370 \\
\hline \multicolumn{4}{|l|}{ Panel B: low FinTech adoption } \\
\hline PANDEMIC_DUMMY & $\begin{array}{l}0.392^{* * *} \\
(0.023)\end{array}$ & & \\
\hline DAILY_CASES & & $\begin{array}{l}0.009^{* * *} \\
(0.001)\end{array}$ & \\
\hline DAILY_DEATHS & & & $\begin{array}{l}0.216^{* * *} \\
(0.057)\end{array}$ \\
\hline Loan originator individual effects & Yes & Yes & Yes \\
\hline Controls & Yes & Yes & Yes \\
\hline LR chi2 & $10,252.819$ & 5555.505 & 5532.129 \\
\hline Prob > chi2 & 0.000 & 0.000 & 0.000 \\
\hline Pseudo-R-squared & 0.164 & 0.219 & 0.218 \\
\hline N & 226,487 & 87,783 & 87,783 \\
\hline
\end{tabular}

impact of the COVID-19 pandemic on defaults in the breakdown of countries' FinTech development. Specifically, we can examine whether FinTech has suppressed the effect of the COVID-19 pandemic on borrower creditworthiness.

Table 6 provides the breakdown of our baseline model in panels based on the level of FinTech adoption in individual countries. We divide our database based on the Global Fintech Index reported by Findexable (2019), which provides a snapshot of local business infrastructure and FinTech ecosystem quality. Panels reported in Table 6 are based on subsamples of countries that are reported to have higher/lower than the median Global FinTech Index. We run the same baseline logit regression model on these two subsamples. We observe that the impact of the COVID-19 pandemic on loan defaults has been more severe in Panel B of Table 6 (lower than median Global FinTech Index). This finding is reflected in the coefficients of COVID-19 proxies that are higher for Panel B of Table 6.

However, regression models with binary responses are not directly comparable (Kuha and Mills 2020). Therefore, we calculate the change in probability of default for incremental changes in COVID-19 cases. We predict the model using the logit function with 


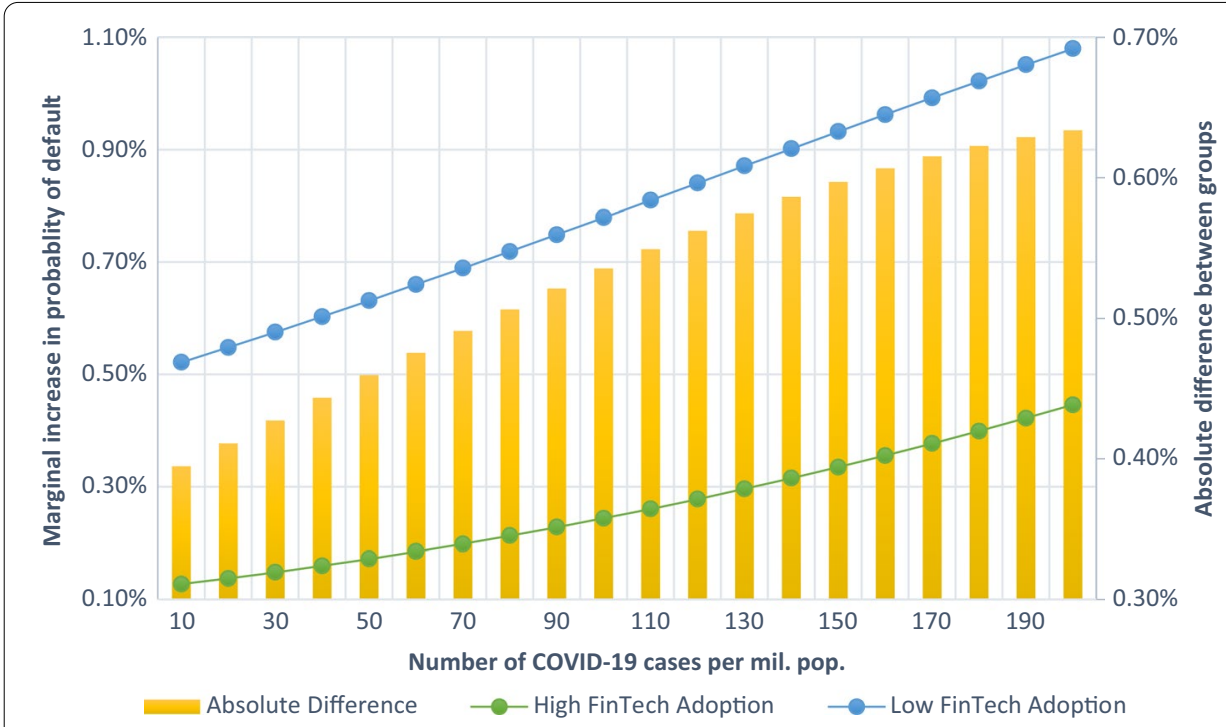

Fig. 1 Change in the probability of default for incremental change in COVID-19 cases (by countries with high and low FinTech adoption). Note: Figure presents marginal changes in the probability of default for countries with high and low FinTech adoption (line plot, left axis). Calculations of marginal changes are based on the coefficients of logit regression reported in Table 6 . The yellow bar plot presents the absolute differences in marginal changes between the two groups (right axis)

estimated coefficients and hold all variables in their mean values (other than reported COVID-19 cases per million population). We report the respective marginal changes in Fig. 1 for 'Low/High FinTech Adoption' subsamples. Figure 1 indicates that the marginal changes in the probability of default were higher in countries with low levels of FinTech adoption. The absolute difference between the two subsamples ranges between 0.39 and $0.63 \%$ for each additional ten daily reported cases of COVID-19 per pillion population (reported as a bar plot in Fig. 1).

Prior studies indicate that FinTech might benefit small businesses and low-income households through better access to finances (Ozili 2018; Demirguc-Kunt et al. 2018). In addition, early studies of the COVID-19 pandemic also highlight the acceleration in financial technologies that can be further leveraged to overcome economic fallout from the pandemic (Arner et al. 2020; Civelek and Xiarewana 2020). In support of these early speculations, our study is the first to empirically indicate that FinTech helps curb the impact of the COVID-19 pandemic on borrower defaults.

We also analyse the monthly impact of COVID-19 risk on loan default risk using the subsamples for each month of 2020 (February to June). Our database is sorted by the last payment date of the loan and reflects borrowers' instant exposure to pandemic risk. We report this additional analysis based on subsamples of the database in Table 7. Loan defaults did not solidly reflect the impact of COVID-19 risk until April 2020. Pandemic induced loan default risk is higher in May to June of 2020 as the coefficients for COVID-19 pandemic risk are consistently significant and positive. The early studies show that the COVID-19 pandemic risk creates substantial stress in financial markets despite some improvements in liquidity conditions (Agosto and Giudici 2020; Demirguc-Kunt et al. 2020a; Kargar et al. 2020). Using monthly analysis, 
Table 7 COVID-19 risk and the likelihood of loan default: monthly subsamples

\begin{tabular}{|c|c|c|}
\hline \multirow[t]{2}{*}{ Variables } & \multicolumn{2}{|c|}{$\mathrm{DV}=\mathrm{DEFAULT}$} \\
\hline & (1) & (2) \\
\hline \multicolumn{3}{|c|}{ Panel A: February listings } \\
\hline DAILY_CASES & $\begin{array}{l}-0.024^{* * *} \\
(0.004)\end{array}$ & \\
\hline DAILY_DEATHS & & $\begin{array}{l}-0.901^{\text {*** }} \\
(0.137)\end{array}$ \\
\hline Controls & Yes & Yes \\
\hline LR chi2 & $22,516.483$ & $22,544.843$ \\
\hline Prob > chi2 & 0.000 & 0.000 \\
\hline Pseudo-R-squared & 0.250 & 0.250 \\
\hline N & 125,546 & 125,546 \\
\hline \multicolumn{3}{|c|}{ Panel B: March listings } \\
\hline DAILY_CASES & $\begin{array}{l}0.001^{* * *} \\
(0.000)\end{array}$ & \\
\hline DAILY_DEATHS & & $\begin{array}{l}0.007^{* * *} \\
(0.001)\end{array}$ \\
\hline Controls & Yes & Yes \\
\hline LR chi2 & $17,501.061$ & $17,280.770$ \\
\hline Prob > chi2 & 0.000 & 0.000 \\
\hline Pseudo-R-squared & 0.101 & 0.100 \\
\hline N & 200,508 & 200,508 \\
\hline \multicolumn{3}{|l|}{ Panel C: April listings } \\
\hline DAILY_CASES & $\begin{array}{l}0.000^{* *} \\
(0.000)\end{array}$ & \\
\hline DAILY_DEATHS & & $\begin{array}{l}-0.000 \\
(0.001)\end{array}$ \\
\hline Controls & Yes & Yes \\
\hline LR chi2 & $29,894.550$ & $29,888.341$ \\
\hline Prob > chi2 & 0.000 & 0.000 \\
\hline Pseudo-R-squared & 0.208 & 0.208 \\
\hline N & 162,099 & 162,099 \\
\hline \multicolumn{3}{|l|}{ Panel D: May listings } \\
\hline DAILY_CASES & $\begin{array}{l}0.006^{* * *} \\
(0.000)\end{array}$ & \\
\hline DAILY_DEATHS & & $\begin{array}{l}0.061^{* * *} \\
(0.001)\end{array}$ \\
\hline Controls & Yes & Yes \\
\hline LR chi2 & $26,130.763$ & $26,350.926$ \\
\hline Prob > chi2 & 0.000 & 0.000 \\
\hline Pseudo-R-squared & 0.348 & 0.351 \\
\hline N & 176,047 & 176,047 \\
\hline \multicolumn{3}{|l|}{ Panel E: June listings } \\
\hline DAILY_CASES & $\begin{array}{l}0.008^{* * *} \\
(0.000)\end{array}$ & \\
\hline DAILY_DEATHS & & $\begin{array}{l}0.087^{* * *} \\
(0.002)\end{array}$ \\
\hline Controls & Yes & Yes \\
\hline LR chi2 & $12,940.095$ & $13,211.923$ \\
\hline Prob > chi 2 & 0.000 & 0.000 \\
\hline Pseudo-R-squared & 0.428 & 0.437 \\
\hline N & 123,614 & 123,614 \\
\hline
\end{tabular}


Table 7 (continued)

Table presents the results of regression analyses based on five panels (for each month from February to June 2020). Results are for logit regression analysis for the likelihood of loan default (DEFAULT). All model specifications employ robust standard errors in parentheses $\left({ }^{*} p<0.10,{ }^{* *} p<0.05,{ }^{* * *} p<0.01\right)$

Table 8 COVID-19 risk and the likelihood of loan default: rating subsamples

\begin{tabular}{|c|c|c|c|}
\hline \multirow[t]{2}{*}{ Variables } & \multicolumn{3}{|c|}{$\mathrm{DV}=\mathrm{DEFAULT}$} \\
\hline & $(1)$ & (2) & (3) \\
\hline \multicolumn{4}{|l|}{ Panel A: 'A' \& 'A-' rated loans } \\
\hline PANDEMIC_DUMMY & $\begin{array}{l}0.491^{* * *} \\
(0.024)\end{array}$ & & \\
\hline DAILY_CASES & & $\begin{array}{l}0.013^{* * *} \\
(0.001)\end{array}$ & \\
\hline DAILY_DEATHS & & & $\begin{array}{l}-0.170^{* * *} \\
(0.061)\end{array}$ \\
\hline Loan originator individual effects & Yes & Yes & Yes \\
\hline Controls & Yes & Yes & Yes \\
\hline LR chi2 & 6449.866 & 3820.249 & 3750.524 \\
\hline Prob > chi2 & 0.000 & 0.000 & 0.000 \\
\hline Pseudo-R-squared & 0.158 & 0.194 & 0.190 \\
\hline N & 181,696 & 86,761 & 86,761 \\
\hline \multicolumn{4}{|l|}{ Panel $B: ' B+{ }^{\prime} \&$ ' $B$ ' rated loans } \\
\hline PANDEMIC_DUMMY & $\begin{array}{l}0.078^{* * *} \\
(0.009)\end{array}$ & & \\
\hline DAILY_CASES & & $\begin{array}{l}0.003^{* * *} \\
(0.000)\end{array}$ & \\
\hline DAILY_DEATHS & & & $\begin{array}{l}0.029^{* * * *} \\
(0.001)\end{array}$ \\
\hline Loan originator individual effects & Yes & Yes & Yes \\
\hline Controls & Yes & Yes & Yes \\
\hline LR chi2 & $60,876.506$ & $49,092.062$ & $49,065.819$ \\
\hline Prob > chi2 & 0.000 & 0.000 & 0.000 \\
\hline Pseudo-R-squared & 0.178 & 0.187 & 0.187 \\
\hline N & 351,415 & 297,125 & 297,125 \\
\hline \multicolumn{4}{|l|}{ Panel $C$ : 'B-,' 'C+' and 'D' rated loans } \\
\hline PANDEMIC_DUMMY & $\begin{array}{l}0.489^{* * *} \\
(0.020)\end{array}$ & & \\
\hline DAILY_CASES & & $\begin{array}{l}0.014^{* * *} \\
(0.001)\end{array}$ & \\
\hline DAILY_DEATHS & & & $\begin{array}{l}0.176^{* * *} \\
(0.026)\end{array}$ \\
\hline Loan originator individual effects & Yes & Yes & Yes \\
\hline Controls & Yes & Yes & Yes \\
\hline LR chi2 & $15,205.346$ & 6110.321 & 6001.120 \\
\hline Prob >chi2 & 0.000 & 0.000 & 0.000 \\
\hline Pseudo-R-squared & 0.206 & 0.197 & 0.193 \\
\hline N & 281,744 & 119,262 & 119,262 \\
\hline
\end{tabular}

Table presents the results of regression analyses based on three panels (by loan ratings). Results are for logit regression analysis for the likelihood of loan default (DEFAULT). All model specifications employ robust standard errors in parentheses $\left({ }^{*} p<0.10,{ }^{* *} p<0.05,{ }^{* * *} p<0.01\right)$ 


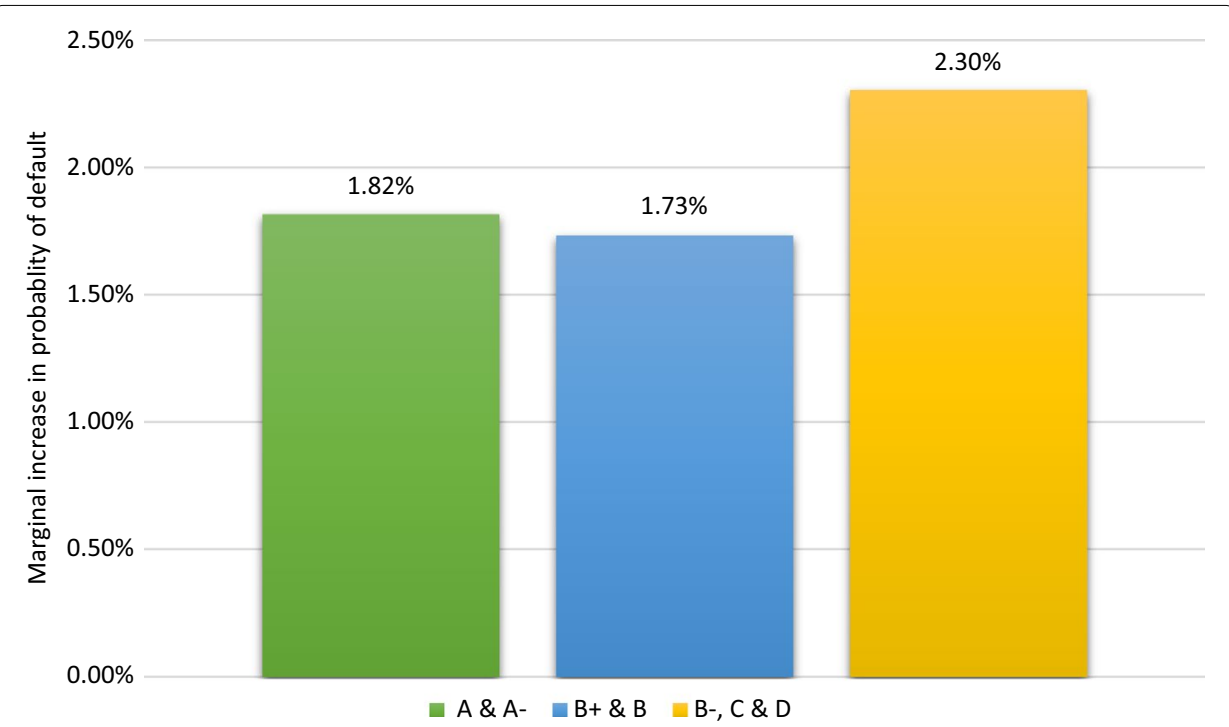

Fig. 2 Marginal change in the probability of default during the pandemic period (by loan ratings). Note: Figure presents marginal increases in the probability of default during the pandemic period based on loan ratings. Calculations of marginal changes are based on the coefficients of logit regression as reported in Table 8

we indicate that those conditions further deteriorated and significantly affected the default risk during May and June 2020.

We highlight that the loan quality significantly increased during the pandemic because of the platform's active role in managing the loans. One can argue that increased loan ratings mechanically cause changes in default or overdue loans. Accordingly, Table 8 provides the results of the analysis using the subsamples based on loan ratings. We divide the database into three groups: Panel A ('A' \& 'A-' rated loans), Panel B ('B+' \& 'B' rated loans) and Panel C ('B-', 'C+' \& 'D' rated loans). All but one regression model reported in Table 8 generate significant positive coefficients for the proxies of COVID-19 risk. The analysis shows that the COVID-19 pandemic risk increases the probability of loan default irrespective of the loan ratings. Thus, regardless of the loan ratings, the likelihood of default risk increases for the whole loan portfolio of the Mintos marketplace during the pandemic.

To assess the change in default risk based on loan ratings, we estimate the marginal magnitude of COVID-19 risk for three rating subgroups. We hold all the control variables at their mean values and estimate the change in the likelihood of default in the post-pandemic period compared with the pre-pandemic period. We base our parameters on the findings reported in Table 8. By estimating the change in the likelihood of default for three rating subgroups, we find that the likelihood of default increase by $1.82 \%$ and $1.73 \%$ for 'A \& A-' and 'B + \& B' rating subgroups, respectively (Fig. 2). The change in the likelihood of default is greater for the ' $\mathrm{B}-, \mathrm{C} \& \mathrm{D}$ ' rating subgroup. On average, loans in this category are $2.30 \%$ more likely to default in the post-pandemic period than the pre-pandemic period.

We also estimate the change in the likelihood of default for each incremental increase in COVID-19 related cases and deaths. Figure 3 reports these changes in the breakdown 


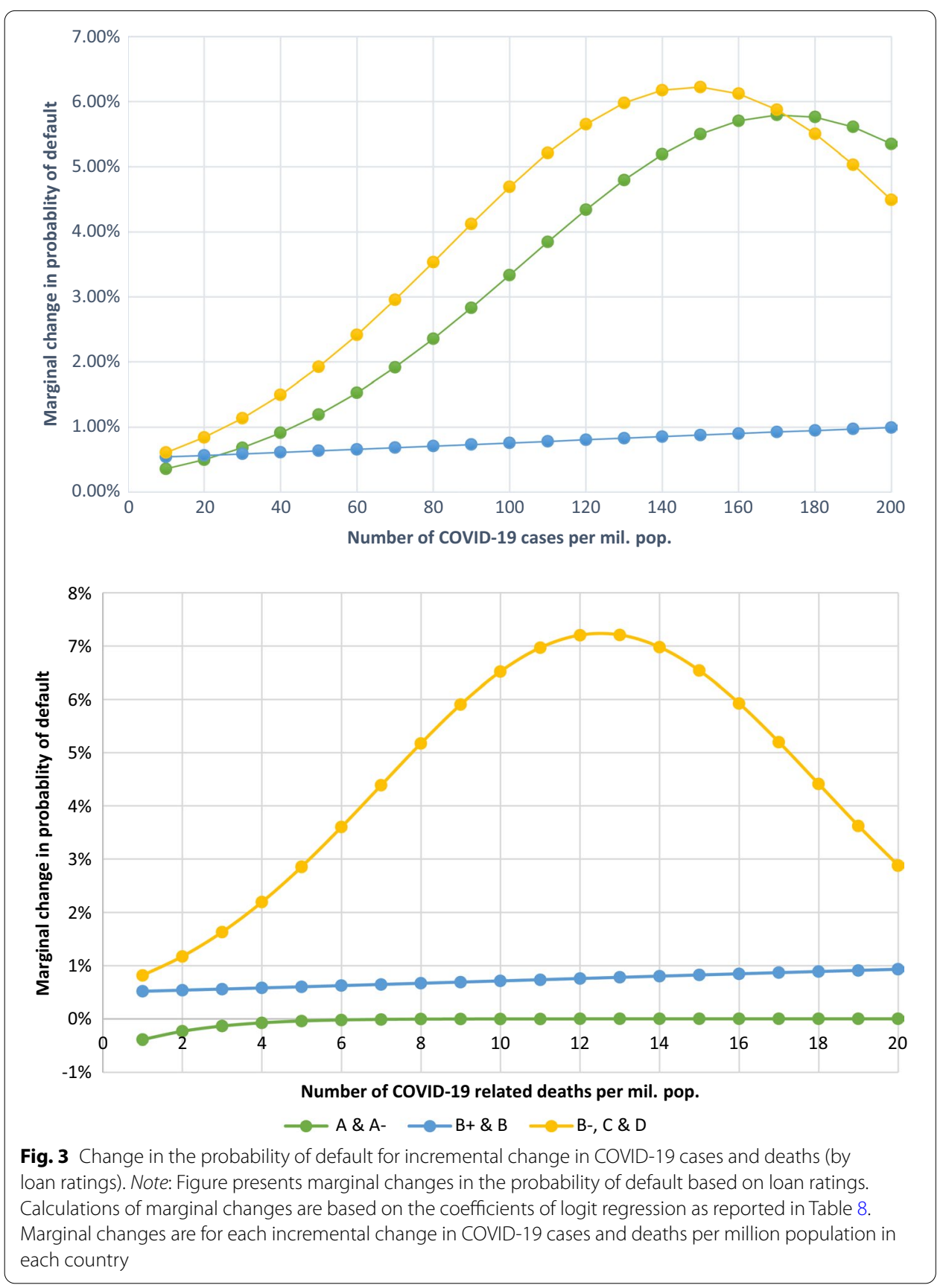

of borrower rating groups. We observe that $\mathrm{B}+$ and $\mathrm{B}$ rated loans are less affected by the changes in COVID-19 related cases and deaths. On the other hand, lower-rated loans ('B-, C \& D' category) are affected by a greater magnitude under each incremental change in COVID-19 cases and deaths. The change in the likelihood of default also decreases after achieving a certain level of peak cases and deaths. Loans with high ratings behave differently when analysed under the incremental changes in COVID-19 cases compared with COVID-19 deaths. The likelihood of default considerably increases for 'A \& A-' rated loans under each incremental change in COVID-19 cases. On 
the contrary, the loans under this classification remain relatively stable in the case of COVID-19 related deaths.

Early studies of Najaf et al. (2021) indicate that risk profiles of borrowers in the US marketplace lending market significantly deteriorated during the COVID-19 pandemic. Our study highlights the same tendency for the European marketplace lending market. Further, the findings of our study indicate that the lower risk profiles transferred into higher defaults with the severity of the spread of the COVID-19 pandemic. Therefore, our results related to loan ratings might have important implications and open room for further research, which we discuss in the last section of this paper.

\section{Robustness tests}

Our sample for the analysis comprises of heterogeneously distributed observations across loan originators. For instance, listings are overrepresented by loan originators based in Latvia, Poland and Spain. ${ }^{7}$ The database also contains disproportionately large amounts of observations for the pre-pandemic period. These features of the database potentially create complications related to sample selection bias. Another potential problem with our sample database is the heterogeneous distribution of loans with a clear ending resolution. This potentially creates a misrepresentation of the sample selection as the loans included in the earlier periods may be defaulted or buyback loans. These loans might be affected by a favourable environment before the pandemic induced turmoil and impede the assessment of COVID-19 risk.

To address these issues, we employ four different procedures. Firstly, we create the subsample consisting of only three countries with the highest number of observations. Secondly, we use a random bootstrap sampling ${ }^{8}$ technique to obtain robust estimates of the relevant coefficients. This method reduces the sampling bias and warrants that our estimates are not affected by the under-weighting or over-weighting of a certain group of observations (Chernick and LaBudde 2014; Tibshirani and Efron 1993). Thirdly, we create a subsample, including only unresolved loans that contain 288,595 loans. Fourthly, we apply the Heckman selection model for sample selection to the binary regression model. We use a binary dependent variable equal to 1 if the loan is 'resolved' having a clear outcome and 0 otherwise. The selection equation is estimated from a much larger sample, including the loans issued before $2020(\mathrm{~N}=28,054,125)$. We instrumentalise the selection in the sample with loan-specific variables, including the loan rating.

Table 9 reports the results of logistic regression after controlling for the above selection bias techniques. We observe that the results are identical to the findings of baseline regressions reported in Table 5 in terms of the coefficient signs and significance. The results are generally robust to all four specifications and similar to the ones reported in baseline regression. We conclude that the detected impact of COVID-19 risk is almost not affected by the selecting mechanisms to construct our sample.

We also indicate the impact of several government interventions in the form of COVID-19 moratoria and public guarantees during the period under consideration [European Banking Authority (EBA) 2020]. Due to the considerable financial support

\footnotetext{
${ }^{7}$ Please, refer to "Appendix 2" for the distribution of the database by county and loan originators.

${ }^{8}$ Stratified bootstrap samples based on loan originators and each month of 2020. Bootstrap sampling replications are conducted 1000 times for each regression estimations.
} 
Table 9 COVID-19 risk and the likelihood of loan default: testing for sampling bias

\begin{tabular}{|c|c|c|c|}
\hline \multirow[t]{2}{*}{ Variables } & \multicolumn{3}{|c|}{$\mathrm{DV}=\mathrm{DEFAULT}$} \\
\hline & (1) & (2) & (3) \\
\hline \multicolumn{4}{|c|}{ Panel A: Three big countries by the number of observations } \\
\hline PANDEMIC_DUMMY & $\begin{array}{l}0.405^{* * *} \\
(0.008)\end{array}$ & & \\
\hline DAILY_CASES & & $\begin{array}{l}0.004^{* * *} \\
(0.000)\end{array}$ & \\
\hline DAILY_DEATHS & & & $\begin{array}{l}0.045^{* * *} \\
(0.001)\end{array}$ \\
\hline Loan originator individual effects & Yes & Yes & Yes \\
\hline Controls & Yes & Yes & Yes \\
\hline Pseudo-R-squared & 0.210 & 0.235 & 0.237 \\
\hline N & 680,694 & 390,133 & 390,133 \\
\hline \multicolumn{4}{|l|}{ Panel B: Bootstrap sampling } \\
\hline PANDEMIC_DUMMY & $\begin{array}{l}0.555^{* * *} \\
(0.007)\end{array}$ & & \\
\hline DAILY_CASES & & $\begin{array}{l}0.004^{* * *} \\
(0.000)\end{array}$ & \\
\hline DAILY_DEATHS & & & $\begin{array}{l}0.036^{* * *} \\
(0.001)\end{array}$ \\
\hline Loan originator individual effects & Yes & Yes & Yes \\
\hline Controls & Yes & Yes & Yes \\
\hline Pseudo-R-squared & 0.129 & 0.173 & 0.170 \\
\hline N & 814,872 & 503,167 & 503,167 \\
\hline \multicolumn{4}{|l|}{ Panel C: Only unresolved loans } \\
\hline PANDEMIC_DUMMY & $\begin{array}{l}0.387^{* * *} \\
(0.010)\end{array}$ & & \\
\hline DAILY_CASES & & $\begin{array}{l}0.007^{* * *} \\
(0.000)\end{array}$ & \\
\hline DAILY_DEATHS & & & $\begin{array}{l}0.067^{* * *} \\
(0.001)\end{array}$ \\
\hline Loan originator individual effects & Yes & Yes & Yes \\
\hline Controls & Yes & Yes & Yes \\
\hline Pseudo-R-squared & 0.274 & 0.345 & 0.347 \\
\hline N & 288,595 & 213,036 & 213,036 \\
\hline \multicolumn{4}{|l|}{ Panel D: Heckman correction } \\
\hline PANDEMIC_DUMMY & $\begin{array}{l}0.088^{* * *} \\
(0.001)\end{array}$ & & \\
\hline DAILY_CASES & & $\begin{array}{l}0.001^{* * *} \\
(0.000)\end{array}$ & \\
\hline DAILY_DEATHS & & & $\begin{array}{l}0.003^{* * *} \\
(0.000)\end{array}$ \\
\hline Loan originator individual effects & Yes & Yes & Yes \\
\hline Controls & Yes & Yes & Yes \\
\hline $\mathrm{N}$ & 814,886 & 503,167 & 503,167 \\
\hline
\end{tabular}

Table presents the results of regression analyses based on four panels. Panel A results are for logit regression analysis for the likelihood of loan default (DEFAULT) with the sample consisting of only three countries with the highest number of observations. Panel B reports the results after the application of bootstrap sampling with stratified sampling based on loan originators and each month of 2020. Panel C results are for logit regression analysis with the sample consisting of only unresolved loans. Panel D reports the results after the application of the Heckman selection model, where the selection in the sample is instrumentalised with loan amount and rating. All model specifications employ robust standard errors in parentheses $\left({ }^{*} p<0.10,{ }^{* *} p<0.05,{ }^{* * *} p<0.01\right)$ 
Table 10 COVID-19 risk and the likelihood of loan default: Robustness tests for government intervention

\begin{tabular}{|c|c|c|c|}
\hline \multirow[t]{2}{*}{ Variables } & \multicolumn{3}{|c|}{ DV $=$ LOANSTATUS } \\
\hline & (1) & $(2)$ & (3) \\
\hline \multicolumn{4}{|l|}{ Panel A: Ordered logit model } \\
\hline PANDEMIC_DUMMY & $\begin{array}{l}-0.165^{* * *} \\
(0.010)\end{array}$ & & \\
\hline DAILY_CASES & & $\begin{array}{l}0.007^{* * *} \\
(0.000)\end{array}$ & \\
\hline DAILY_DEATHS & & & $\begin{array}{l}0.074^{* * *} \\
(0.001)\end{array}$ \\
\hline Loan originator individual effects & Yes & Yes & Yes \\
\hline Controls & Yes & Yes & Yes \\
\hline LR chi2 & $90,191.487$ & $60,621.580$ & $59,476.467$ \\
\hline Prob >chi2 & 0.000 & 0.000 & 0.000 \\
\hline Pseudo-R-squared & 0.189 & 0.213 & 0.221 \\
\hline N & 288,356 & 212,917 & 212,917 \\
\hline \multirow[t]{2}{*}{ Variables } & \multicolumn{3}{|c|}{$\mathrm{DV}=\mathrm{ONLYDEFAULTS}$} \\
\hline & (1) & (2) & (3) \\
\hline \multicolumn{4}{|c|}{ Panel B: Only default loans as dependent variable } \\
\hline PANDEMIC_DUMMY & $\begin{array}{l}0.687^{* * *} \\
(0.007)\end{array}$ & & \\
\hline DAILY_CASES & & $\begin{array}{l}0.007^{* * *} \\
(0.000)\end{array}$ & \\
\hline DAILY_DEATHS & & & $\begin{array}{l}0.061^{* * *} \\
(0.001)\end{array}$ \\
\hline Loan originator individual effects & Yes & Yes & Yes \\
\hline Controls & Yes & Yes & Yes \\
\hline LR chi2 & $54,149.904$ & $39,331.896$ & $37,516.142$ \\
\hline Prob > chi2 & 0.000 & 0.000 & 0.000 \\
\hline Pseudo-R-squared & 0.150 & 0.160 & 0.153 \\
\hline N & 814,872 & 503,153 & 503,153 \\
\hline
\end{tabular}

from various governments during the pandemic period, there is a possibility of default loans being effectively bailed out by the governments. In fact, Mintos continued serving late loans but fell under the government moratoria and public guarantee. However, the platform classifies these loans as overdue loans instead of writing them off (as default or buyback) from the books (Mintos 2020).

To mitigate the impact of government interventions, we estimate two separate regression models with different dependent variables than the baseline regression. First, we run an ordered logit model in which the dependent variable is the status of the unresolved loan ('current', 'in grace period' or late loans ${ }^{9}$ ). Accordingly, the dependent variable (LOANSTATUS) takes one of the six values, and the regression sample consists of 
only unresolved loans. Second, we run the logit regression with the dependent variable, which takes the value of 1 if the loan is classified as default or buyback and 0 otherwise.

The results are generally robust to this change in the regression method with the estimation results from Model (2) and (3) of Table 10 Panel A, similar to those reported in baseline regression. The log-likelihood of loan status transferring from lower group to one level higher group (e.g. from 'current' status to 'in grace period' status) increases with an increase in COVID-19 related daily cases and deaths. In Model (1) of Table 10 Panel A, the dummy variable representing the impact of the COVID-19 pandemic is negative on loan status. A possible explanation could be that most loans from the early months of 2020 are already resolved, coinciding with the pre-pandemic period. This result might also indicate some impact of government interventions as more borrowers apply for extensions. Nevertheless, we observe from Panel B of Table 10 that the coefficients for the variables representing COVID-19 risk remain to be significantly positive. Thus, there is some indication that government interventions only delayed the occurrence of defaults in the marketplace lending market. Our additional analyses mostly validate the baseline regression model results and provide some further insights into the impact of COVID-19 risk on loan defaults. However, the findings related to the impact of government interventions require further analyses that are duly mentioned in the last section of this paper.

\section{Discussion and conclusion}

\section{Contributions}

The rapidly growing FinTech industry first-time witnesses global pandemic since their revolution of platform-based financing. As the current COVD-19 pandemic related crisis progresses into the later stage, financial hardship experienced by households, businesses, and public sector organisations might also transfer into a more severe stage. As one of the risky financing sectors, marketplace lending might experience a wave of defaults during 2021. This stream of defaults tends to impact the resilience of the industry and force platforms to reconsider their risk management models. On the other hand, the pandemic can help transform 'shadow banking' with an extensive emphasis on alternative lending practices (Sindreu 2020). As one of the prominent facets of alternative lending, the marketplace lending market may become mainstream from its current niche position.

Our study explores the implication of COVID-19 pandemic risk on the likelihood of marketplace loan defaults using the loan book database of Mintos. Prior studies have not yet assessed the default risk within the context of the COVID-19 pandemic. Due to the pandemic's ongoing and rapidly evolving nature, the implication of COVID-19 pandemic-related risk and its related financial consequences are little understood.

This study documents evidence of the early detrimental impact of the pandemic induced economic turmoil on the marketplace lending market. We provide the first evidence that COVID-19 pandemic risk considerably increases the likelihood of loan defaults in the Mintos marketplace lending platform. By employing the logit regression model, we estimate that the likelihood of default, on average, increases from 0.056 in the pre-pandemic period to 0.079 in the post-pandemic period. Pandemic induced loan default risk reached its highest magnitude during May and June of 2020. We empirically document higher levels of FinTech adoption reduces adverse effects of COVID-19 on the 
probability of default. We also highlight a significant difference in the marginal impact of COVID-19 risk among the loan rating subgroups. Borrowers with lower credit ratings are most affected during the pandemic period.

During the pandemic induced turmoil, the findings related to COVID-19 risk have important implications. Early studies indicate that the COVID-19 pandemic has a detrimental impact on the financial sector performance, liquidity and risk profile (Baig et al. 2020; Demirguc-Kunt et al. 2020b; Najaf et al. 2021). A recent study by Ari et al. (2020) indicates that banking sector NPLs peaked at about $20 \%$ of total loans on average during the past crises since 1900. We suggest that current pandemic-related risk creates not only a liquidity crisis but also an underperformance for non-bank financial institutions. In fact, households and businesses experience financial distress, which increases default risk in one of the risky sectors of financing.

Our study is the first one that reveals how borrowers' creditworthiness behaved during the pandemic's early period. We also provide evidence that FinTech has suppressed the impact of the COVID-19 pandemic on borrower distress. Thus, this study allows for a better understanding and quantifying risks related to FinTech loans during the pandemic and periods of overall economic distress. It fills the gap in the existing literature by developing a cross country model that is tested via econometric analysis. Our insights into marketplace lending contribute to the literature by providing a deeper understanding of borrower behaviour under financial distress. This study's findings in terms of COVID-19 risk can guide platform management in overcoming or controlling various risk factors. At the same time, the findings related to FinTech adoption might be used by governing bodies for further adoption and regulation of the FinTech sector. The model used in our study by including both loan and economy specific variables might serve as a framework of risk management in marketplace lending platforms.

Considering beyond borrower-specific factors, these models allow for comprehensive estimation of credits risk, borrower ratings, informing investors about potential risk levels and setting up the 'provision fund'. Based on the same evidence, forecasting mechanisms may be put in place for mitigating risk factors in a way that were not possible before. For instance, the sensitivity of credit risk to external factors is reflected in variable coefficients in regression analyses. These coefficients highlight the sensitivity of default risk to the changes in a pandemic or its severity (reflected in the number of reported cases and deaths). These coefficients may be used for stress testing of marketplace lending portfolios under certain conditions, such as decreased consumer confidence.

\section{Limitations and future research avenues}

As one of the early studies on the COVID-19 pandemic, our study has some limitations, which may provide important avenues for future research. First, we find some discrepancies in the analysis of COVID-19 risk in the breakdown of loan ratings. Higher rated loans ('A\&A-') are affected by COVID-19 risk by a higher magnitude when measured by the case numbers than death numbers (Fig. 2). A possible explanation for this can be that deaths are the lagging indicator. Cases usually indicate early changes in the pandemic turmoil where both investors and borrowers are keen to cash in, while the true impact of the pandemic related disruptions did not hit the economy (Langreth et al. 2020). The number of COVID-19 related deaths, lagging a couple of weeks behind, might represent the later period of the pandemic related insolvency of borrowers. Further ascertaining 
this hypothesis is out of this study's scope and requires further disclosure from the marketplace lending platforms. Future research might examine this specific aspect of loan lending if more borrower information becomes available.

Second, we focus on one specific marketplace lending platform (Mintos). Although our study includes the loans issued by various loan originators located in multiple countries of Continental Europe, the generalisation of our findings might be problematic. For example, other platforms might practice different selection mechanisms or loan risk assessment methods. Therefore, future research could test whether our findings are generalisable to marketplace lending markets in other geographical areas or other non-bank lending markets. For instance, future studies can analyse marketplace lending markets in America and Asia with regards of their exposure to COVID-19 pandemic risk.

Third, marketplace lending markets are characterized by a high interdependence between various players of the market like borrowers, platforms and issuing countries. Therefore, it is important to include financial contagion risk in the measurement of default risk probability. Future studies can analyse the default risk from the perspective of contagion risk. In this regard, theoretical considerations of the full network contagion model (Avdjiev et al. 2019) or the network-based credit risk models (Giudici et al. 2020) can be used for further extension of the modelling of this study. Nevertheless, given that Mintos is one of the most diverse and long-serving marketplace lenders in Continental Europe, it is unlikely that other platforms can match the same market coverage. Still, it would be useful to examine how country-level characteristics or interplatform competition could influence the credit risk incurred by investors.

Fourth, we consider the FinTech adoption as a cushion for curbing the negative impact of COVID-19 risk on marketplace lending market defaults. We divide our database into two separate groups based on FinTech Development Index (Findexable 2019) and calculate marginal changes in default probabilities in these two groups. However, we believe that this issue can be further extended in future studies. For instance, further analysis might estimate the indirect impact of the COVID-19 pandemic via FinTech adoption. In doing so, future studies can use mediation analysis and use alternative proxies for FinTech adoption. Future studies can also consider the role of digital finance, credit market efficiency and financial inclusion in mediating the impact of COVID-19 on defaults.

Finally, we have to note the limited scope of this study regarding the long-term impact of COVID-19 risk on the marketplace lending market. This study analysed the impact of the pandemic based on the database with a limited time span, essentially during the first wave of the pandemic. However, extending our study to the impact of subsequent second and third waves of the pandemic requires different set of conceptual framework and modelling. Particularly, after the introduction of vaccines the emphasis is shifted from case and death numbers to vaccination and hospitalization rates. We also believe that the full impact of the pandemic to credit risk can be observed by the end of 2021. By this time, it is expected that various government-imposed restrictions are lifted, and short-term liquidity problems of businesses and households are transferred into insolvency. Therefore, future studies can repeat this exercise in future when the longer timespan data become available. 


\section{Appendix 1}

See Table 11.

Table 11 Description of variables

\begin{tabular}{|c|c|c|}
\hline Variable & Description of variable & Source \\
\hline \multicolumn{3}{|c|}{ Dependent variables } \\
\hline DEFAULT & $\begin{array}{l}\text { Current status of individual loan. } \\
\text { Dummy variable equal to } 1 \text { if the } \\
\text { loans is overdue, defaulted or } \\
\text { buyback and } 0 \text { otherwise (current or } \\
\text { repaid) }\end{array}$ & Mintos \\
\hline \multicolumn{3}{|c|}{ Independent variables, pandemic indicator variables } \\
\hline PANDEM_DUM & $\begin{array}{l}\text { Dummy variable equal to } 1 \text { for the } \\
\text { dates later than March 11, } 2020 \text { (The } \\
\text { date WHO declared COVID-19 as } \\
\text { pandemic) and } 0 \text { otherwise }\end{array}$ & World Health Organization (2020) \\
\hline DAILY_CASES & $\begin{array}{l}\text { Number of reported daily cases of } \\
\text { COVID-19 per million population in } \\
\text { country } i \text { at time } t \text { (daily observations, } \\
\text { log values) }\end{array}$ & $\begin{array}{l}\text { World Health Organization (2020), Johns } \\
\text { Hopkins University \& Medicine (2020) }\end{array}$ \\
\hline DAILY_DEATHS & $\begin{array}{l}\text { Number of reported daily COVID-19 } \\
\text { related deaths per million population } \\
\text { in country } i \text { at time } t \text { (daily observa- } \\
\text { tions, log values) }\end{array}$ & $\begin{array}{l}\text { World Health Organization (2020), Johns } \\
\text { Hopkins University \& Medicine (2020) }\end{array}$ \\
\hline \multicolumn{3}{|c|}{ Independent variables, macroeconomic and country-specific variables } \\
\hline ESI & $\begin{array}{l}\text { The EU Economic sentiment indicator } \\
\text { (composite measure, average }=100, \\
\text { log values) }\end{array}$ & $\begin{array}{l}\text { Full business and consumer survey results, } \\
\text { European Commission https://ec.europa. } \\
\text { eu/info/business-economy-euro/indic } \\
\text { ators-statistics/economic-databases/ } \\
\text { business-and-consumer-surveys_en }\end{array}$ \\
\hline MARKET_VOL & $\begin{array}{l}\text { Change in daily stock market index } \\
\text { values of country i at time t (percent- } \\
\text { age points) }\end{array}$ & $\begin{array}{l}\text { Yahoo.Finance, https://finance.yahoo. } \\
\text { com/world-indices/ }\end{array}$ \\
\hline AAR & $\begin{array}{l}\text { Annualised agreed rate by credit and } \\
\text { other institutions in country } i \text { at time } t \\
\text { (monthly, percentage points }\end{array}$ & $\begin{array}{l}\text { ECB Statistical Data Warehouse http:// } \\
\text { sdw.ecb.europa.eu/ }\end{array}$ \\
\hline UNEMPL & $\begin{array}{l}\text { Unemployment rate for each country } \\
\text { (Monthly, seasonally adjusted, per- } \\
\text { centage points) }\end{array}$ & $\begin{array}{l}\text { OECD (2020), Unemployment rate (indica- } \\
\text { tor). https://doi.org/10.1787/b86d1fc8- } \\
\text { en (Accessed on } 14 \text { June 2020) }\end{array}$ \\
\hline \multicolumn{3}{|c|}{ Independent variables, loan-specific variables } \\
\hline EXT_SCHED & $\begin{array}{l}\text { Dummy variable representing the } \\
\text { restructuring of a loan. Equal to } 1 \text { if } \\
\text { the original maturity date of the loan } \\
\text { has been increased by more than } \\
60 \text { days, } 0 \text { otherwise }\end{array}$ & Mintos \\
\hline COLLATERAL & $\begin{array}{l}\text { Dummy variable representing the } \\
\text { loan type in terms of a provision of } \\
\text { collateral. Equal to } 1 \text { if the loan is col- } \\
\text { lateralised, } 0 \text { otherwise }\end{array}$ & Mintos \\
\hline INTEREST & $\begin{array}{l}\text { Maximum interest rate accepted in } \\
\text { the loan application (\%, log values) }\end{array}$ & Mintos \\
\hline LOAN_TERM & $\begin{array}{l}\text { Duration of loan (in months, log } \\
\text { values) }\end{array}$ & Mintos \\
\hline AMOUNT & Value of individual loan (log values) & Mintos \\
\hline RATING & $\begin{array}{l}\text { 'Mintos Rating' issued by the rating } \\
\text { model ranging between } A+(1) \text { and } \\
D(7)\end{array}$ & Mintos \\
\hline LOANTYPE & $\begin{array}{l}\text { The loan type: 1-Business Loan, 2-Car } \\
\text { Loan, 3-Invoice Financing, 4-Pawnbro- } \\
\text { king Loan, 5- Personal Loan, 0-Other }\end{array}$ & Mintos \\
\hline
\end{tabular}




\section{Appendix 2}

See Table 12.

Table 12 Breakdown of loans by loan originators in pre- and post-pandemic period

\begin{tabular}{|c|c|c|c|c|c|}
\hline \multirow[t]{2}{*}{ Country } & \multirow[t]{2}{*}{ Loan originator } & \multicolumn{2}{|c|}{ Pre-pandemic } & \multicolumn{2}{|c|}{ Post-pandemic } \\
\hline & & $N$ & $\%$ & $N$ & $\%$ \\
\hline Bulgaria & CashCredit & 7861 & 1.46 & 3290 & 1.19 \\
\hline Bulgaria & Credissimo & 6549 & 1.22 & 1850 & 0.67 \\
\hline Bulgaria & ITF Group & 317 & 0.06 & 190 & 0.07 \\
\hline Bulgaria & Mogo & 312 & 0.06 & 72 & 0.03 \\
\hline Bulgaria & StikCredit & 4598 & 0.85 & 1800 & 0.65 \\
\hline Czech Republic & Creamfinance & 1910 & 0.35 & 1120 & 0.41 \\
\hline Czech Republic & Creditstar & 2350 & 0.44 & 766 & 0.28 \\
\hline Denmark & Creamfinance & 2605 & 0.48 & 650 & 0.24 \\
\hline Denmark & Mozipo Group & 4 & 0.00 & - & - \\
\hline Denmark & Simbo & 30,563 & 5.67 & 8258 & 2.99 \\
\hline Estonia & Capitalia & 2 & 0.00 & 2 & 0.00 \\
\hline Estonia & Creditstar & 7247 & 1.35 & 2498 & 0.90 \\
\hline Estonia & ESTO & 3559 & 0.66 & 2998 & 1.09 \\
\hline Estonia & Mogo & 1254 & 0.23 & 218 & 0.08 \\
\hline Estonia & Placet & 763 & 0.14 & 588 & 0.21 \\
\hline Finland & BB Finance Group & 9469 & 1.76 & 1186 & 0.43 \\
\hline Finland & Creditstar & 1645 & 0.31 & 659 & 0.24 \\
\hline Latvia & AgroCredit & 31 & 0.01 & 9 & 0.00 \\
\hline Latvia & Banknote & 62,704 & 11.64 & 47,736 & 17.28 \\
\hline Latvia & Bino & 64,000 & 11.88 & 14,330 & 5.19 \\
\hline Latvia & Capitalia & 333 & 0.06 & 135 & 0.05 \\
\hline Latvia & Creamfinance & 889 & 0.17 & 896 & 0.32 \\
\hline Latvia & Hipocredit & 12 & 0.00 & 7 & 0.00 \\
\hline Latvia & Mogo & 298 & 0.06 & 84 & 0.03 \\
\hline Latvia & Mogo Renti & 300 & 0.06 & 268 & 0.10 \\
\hline Latvia & VIZIA & 1754 & 0.33 & 3428 & 1.24 \\
\hline Lithuania & Capitalia & 104 & 0.02 & 12 & 0.00 \\
\hline Lithuania & Hipocredit & 8 & 0.00 & 4 & 0.00 \\
\hline Lithuania & Mogo & 605 & 0.11 & 199 & 0.07 \\
\hline Lithuania & Mozipo Group & 2452 & 0.46 & 456 & 0.17 \\
\hline Lithuania & Placet & 1544 & 0.29 & 572 & 0.21 \\
\hline Poland & Alfakredyt & 3588 & 0.67 & 3816 & 1.38 \\
\hline Poland & Capital Service & 7263 & 1.35 & 345 & 0.12 \\
\hline Poland & Creamfinance Poland & 18,528 & 3.44 & 19,232 & 6.96 \\
\hline Poland & Creditstar & 27,166 & 5.04 & 13,671 & 4.95 \\
\hline Poland & Dziesiatka Finanse & 894 & 0.17 & 105 & 0.04 \\
\hline Poland & Everest Finanse & 31,382 & 5.83 & 10,317 & 3.73 \\
\hline Poland & Kuki & 95,755 & 17.78 & 42,463 & 15.37 \\
\hline Romania & Credius & 1122 & 0.21 & - & - \\
\hline Romania & Mikro Kapital Romania & 13 & 0.00 & 11 & 0.00 \\
\hline Romania & Mogo & 304 & 0.06 & 16 & 0.01 \\
\hline Romania & Mozipo Group & 716 & 0.13 & 252 & 0.09 \\
\hline Spain & Creamfinance Spain & 14,232 & 2.64 & 6806 & 2.46 \\
\hline Spain & Creditstar & 19,323 & 3.59 & 6915 & 2.50 \\
\hline Spain & Dineo Credito & 24,989 & 4.64 & 21,243 & 7.69 \\
\hline
\end{tabular}


Table 12 (continued)

\begin{tabular}{|c|c|c|c|c|c|}
\hline \multirow[t]{2}{*}{ Country } & \multirow[t]{2}{*}{ Loan originator } & \multicolumn{2}{|c|}{ Pre-pandemic } & \multicolumn{2}{|c|}{ Post-pandemic } \\
\hline & & $\mathrm{N}$ & $\%$ & $N$ & $\%$ \\
\hline Spain & ID Finance & 62,523 & 11.61 & 52,924 & 19.16 \\
\hline United Kingdom & Evergreen & 5493 & 1.02 & 175 & 0.06 \\
\hline United Kingdom & Novaloans & 8897 & 1.65 & 3658 & 1.32 \\
\hline United Kingdom & Peachy & 426 & 0.08 & - & - \\
\hline Total & & 538,656 & 100.00 & 276,230 & 100.00 \\
\hline
\end{tabular}

Total values are in bold

\section{Abbreviations}

OECD: Organisation for Economic Co-operation and Development; SMEs: Small- and medium-sized enterprises; SSE: Shanghai Stock Exchange; WHO: World Health Organization; NPL: Non-performing loans; EU: European Union; EBA: European Banking Authority.

\section{Acknowledgements}

Not applicable.

\section{Authors' contributions}

AN: Conceptualisation, methodology, software, data curation, writing-original draft preparation, visualisation, formal analysis, software. SS: Supervision, validation, writing- reviewing and editing. All authors read and approved the final manuscript.

\section{Funding}

No funding was received.

\section{Availability of data and materials}

Data is available on request.

Declaration

Ethical approval

No research was conducted in this study on humans or animals.

\section{Competing interests}

No competing interests to report.

\section{Author details}

${ }^{1}$ University of New South Wales, Sydney, Australia. ${ }^{2}$ University of Southern Queensland, Darling Heights, Australia.

Received: 27 March 2021 Accepted: 6 October 2021

Published online: 08 December 2021

\section{References}

Agosto A, Giudici P (2020) COVID-19 contagion and digital finance. Digit Finance Short Commun 2:159-167. https://doi. org/10.1007/s42521-020-00021-3

Ali A, Daly K (2010) Macroeconomic determinants of credit risk: recent evidence from a cross country study. Int Rev Financ Anal 19(3):165-171. https://doi.org/10.1016/j.irfa.2010.03.001

Ali M, Alam N, Rizvi SAR (2020) Coronavirus (COVID-19)—an epidemic or pandemic for financial markets. J Behav Exp Finance 27:100341

Ari A, Chen S, Ratnovski L (2020) The dynamics of non-performing loans during banking crises: a new database. ECB Working Paper Series, No 2395/April 2020

Arner DW, Barberis JN, Walker J, Buckley RP, Dahdal AM, Zetzsche DA (2020) Digital finance and the COVID-19 crisis. University of Hong Kong Faculty of Law Research Paper No. 2020/017. Accessed from https://ssrn.com/abstract= 3558889

Auer R, Cornelli G, Frost J (2020) Covid-19, cash, and the future of payments. BIS Bulletin No. 3. Bank for International Settlements, April 3 2020. Accessed from https://www.bis.org/publ/bisbull03.pdf

Aveni T, Qu C, Hsu K, Zhang A, Lei X, Hemrika L. New Insights Into An Evolving P2P Lending Industry: how shifts in roles and risk are shaping the industry. 2015; Retrieved from: https://www.findevgateway.org/sites/default/files/publi cations/files/new_insights_into_an_evolving_p2p_lending_industry_positiveplanet2015.pdf

Avdjiev S, Giudici P, Spelta A (2019) Measuring contagion risk in international banking. J Financ Stab 42:36-51

Baig A, Butt HA, Haroon O, Rizvi SAR (2020) Deaths, panic, lockdowns and US equity markets: the case of COVID-19 pandemic. Available at SSRN 3584947. Accessed from https://ssrn.com/abstract=3584947

Baldwin R, Di Mauro BW (2020) Economics in the time of COVID-19. Centre for Economic Policy Research, London Balyuk T, Davydenko S (2019) Reintermediation in FinTech: evidence from online lending. Michael J. Brennan Irish Finance Working Paper Series Research Paper No. 18-17 
Bofondi M, Ropele T (2011) Macroeconomic determinants of bad loans: evidence from Italian banks. Occasional papers No. 89, March 2011. Bank of Italy, Economic Research and International Relations Area. Accessed from https://EconP apers.repec.org/RePEc:bdi:opques:qef_89_11

Bolt W, de Haan L, Hoeberichts M, van Oordt MRC, Swank J (2012) Bank profitability during recessions. J Bank Finance 36(9):2552-2564

Bose S, Shams S, Ali MJ, Mihret D (2021) COVID-19 impact, sustainability performance and firm value: international evidence. Acc Finance 61(2). https://doi.org/10.1111/acfi.12801

Cai S, Lin X, Xu D, Fu X (2016) Judging online peer-to-peer lending behavior: a comparison of first-time and repeated borrowing requests. Inf Manag 53(7):857-867

Cecchetti SG, Schoenholtz KL (2020) Finance and Technology: What is changing and what is not. Korea Institute of Finance. Retrieved from: http://fakultaetsseminar.uni-mannheim.de/material/PaperCecchetti.pdf

Chernick MR, LaBudde RA (2014) An introduction to bootstrap methods with applications to R. Wiley, New York

Civelek ME, Xiarewana B (2020) Effects of Covid-19 on China and the world economy: Birth pains of the post-digital ecosystem. J Int Trade Logist Law 6(1):147-157

Cumming D, Hornuf L (2018) The economics of crowdfunding. Startups, portals and investor behavior. Palgrave Macmillan, Cham

Dawson E (2020, September 28, 2020) There should be no return to the world before the virus. Financ Rev. Accessed from https://www.afr.com/policy/economy/there-should-be-no-return-to-the-world-before-the-virus-20200927-p55zq6

Demirguc-Kunt A, Klapper L, Singer D, Ansar S, Hess J (2018) The Global Findex Database 2017: measuring financial inclusion and the FinTech revolution. The World Bank, Washington, DC

Demirguc-Kunt A, Lokshin M, Torre I (2020a) The sooner, the better: the early economic impact of non-pharmaceutical interventions during the COVID-19 pandemic. World Bank Policy Research Working Paper. Washington, DC

Demirguc-Kunt A, Pedraza A, Ruiz-Ortega C (2020b) Banking sector performance during the Covid-19 crisis. Policy Research Working Paper; No. 9363. The World Bank, Washington, DC

Diamond DW (1984) Financial intermediation and delegated monitoring. Rev Econ Stud 51(3):393-414

Dushnitsky G, Guerini M, Piva E, Rossi-Lamastra C (2016) Crowdfunding in Europe: determinants of platform creation across countries. Calif Manage Rev 58(2):44-71

EBA (2020) Banks report a significant use of COVID-19 moratoria and public guarantees. European Banking Authority. Accessed from https://www.eba.europa.eu/banks-report-significant-use-covid-19-moratoria-and-public-guarantees

Elnahas A, Kim D, Kim I (2018) Natural disaster risk and corporate leverage. Available at SSRN 3123468

Emekter R, Tu Y, Jirasakuldech B, Lu M (2015) Evaluating credit risk and loan performance in online Peer-to-Peer (P2P) lending. Appl Econ 47(1):54-70. https://doi.org/10.1080/00036846.2014.962222

Findexable (2019) The Global Fintech Index 2020. Findexable Limited \& The Global Fintech Index. Accessed from www. findexable.com

Flögel F, Beckamp M (2020) Will FinTech make regional banks superfluous for small firm finance? Observations from soft information-based lending in Germany. Econ Notes 49(2):e12159

Fu J, Mishra M (2020) The global impact of COVID-19 on FinTech adoption. Swiss Finance Institute Research Paper (20-38). University of Zurich

Galema R (2020) Credit rationing in P2P lending to SMEs: do lender-borrower relationships matter? J Corp Finance 65:101742. https://doi.org/10.1016/j.jcorpfin.2020.101742

Giudici P, Hadji-Misheva B, Spelta A (2020) Network based credit risk models. Qual Eng 32(2):199-211

Goodell JW (2020) COVID-19 and finance: agendas for future research. Financ Res Lett 35:101512. https://doi.org/10. 1016/j.frl.2020.101512

Gordon G, Jones JB (2020) Loan delinquency projections for COVID-19. Federal Reserve Bank of Richmond, Richmond. Accessed from https://papers.ssrn.com/sol3/papers.cfm?abstract_id=3650562

Greenwald BC, Stiglitz JE (1993) Financial market imperfections and business cycles. Quart J Econ 108(1):77

Haacker M (2004) The impact of HIV/AIDS on government finance and public services. In: Haacker M (ed) The macroeconomics of HIV/AIDS. International Monetary Fund, Washington, D.C.

lyer R, Khwaja Al, Luttmer EF, Shue K (2016) Screening peers softly: inferring the quality of small borrowers. Manag Sci 62(6):1554-1577

lyke BN (2020) COVID-19: the reaction of US oil and gas producers to the pandemic. Energy Res Lett 1:13912

Jagtiani J, Lemieux C (2017) FinTech lending: financial inclusion, risk pricing, and alternative information. FRB of Philadelphia Working Paper No. 17-17. Available at SSRN: https://ssrn.com/abstract=3005260

Kargar M, Lester B, Lindsay D, Liu S, Weill P-O, Zúñiga D (2020) Corporate bond liquidity during the COVID-19 crisis. National Bureau of Economic Research Working Paper Series, No. 27355. Accessed from http://www.nber.org/ papers/w27355. https://doi.org/10.3386/w27355

Kou G, Xu Y, Peng Y, Shen F, Chen Y, Chang K, Kou S (2021) Bankruptcy prediction for SMEs using transactional data and two-stage multiobjective feature selection. Decis Supp Syst 140:113429. https://doi.org/10.1016/j.dss.2020.113429

Kuha J, Mills C (2020) On group comparisons with logistic regression models. Sociol Methods Res 49(2):498-525

Laeven L, Valencia F (2013) Systemic banking crises database. IMF Econ Rev 61 (2):225-270

Lagoarde-Segot T, Leoni PL (2013) Pandemics of the poor and banking stability. J Bank Financ 37(11):4574-4583

Langreth R, Court E, Cortez MF (2020, 27 June 2020) Virus fatality picture is obscured by the ultimate lagging indicator. Bloomberg, Prognosis. Accessed from https://www.bloomberg.com/news/articles/2020-06-26/virus-fatality-pictu re-is-obscured-by-the-ultimate-lagging-indicator

Leoni PL (2013) HIV/AIDS and banking stability in developing countries. Bull Econ Res 65(3):225-237

Li W, Ding S, Chen Y, Yang S (2018) Heterogeneous ensemble for default prediction of peer-to-peer lending in China. IEEE Access 6:54396-54406

Li X, Xie Y, Lin J-H (2021) COVID-19 outbreak, government capital injections, and shadow banking efficiency. Appl Econ 53(4):495-505. https://doi.org/10.1080/00036846.2020.1808183

Mintos (2020) Moratorium for borrowers: international overview by Mintos (updated). Accessed from https://www. mintos.com/blog/moratorium-for-borrowers-international-overview-by-mintos/ 
Mollick E (2014) The dynamics of crowdfunding: an exploratory study. J Bus Ventur 29(1):1-16

Najaf K, Subramaniam RK, Atayah OF (2021) Understanding the implications of FinTech peer-to-peer (P2P) lending during the COVID-19 pandemic. J Sustain Finance Invest. https://doi.org/10.1080/20430795.2021.1917225

Nigmonov A, Daradkeh H (2020) From one crisis to another: impact of COVID-19 pandemic on peer-to-peer lending market. Forthcoming, Financial transformations beyond the Covid-19 health crisis. World Scientific Publishing. Available at SSRN: https://doi.org/10.2139/ssrn.3738075

Nigmonov A, Shams S, Alam K (2021) Macroeconomic determinants of loan defaults: evidence from the U.S. peer-to-peer lending market. Res Int Bus Finance 59:101516

Ning Y, Wang W, Yu B (2015) The driving forces of venture capital investments. Small Bus Econ 44(2):315-344

Okorie DI, Lin B (2021) Stock markets and the COVID-19 fractal contagion effects. Finance Res Lett 38:101640. https://doi. org/10.1016/j.frl.2020.101640

Organisation for Economic Co-operation and Development (OECD) (2020) Corporate sector vulnerabilities during the Covid-19 outbreak: assessment and policy responses. OECD, Geneva

Ozili PK (2018) Impact of digital finance on financial inclusion and stability. Borsa Istanbul Rev 18(4):329-340

Peckham R (2013) Economies of contagion: financial crisis and pandemic. Econ Soc 42(2):226-248

RateSetter (2020) RateSetter increases provision and temporarily reduces interest rates. Accessed from https://www.rates etter.com/blog/sp_announcement

Ryan SG, Zhu C (2018) FinTech isn't so different from traditional banking: trading off aggregation of soft information for transaction processing efficiency. Available at SSRN 3212902

Sadang A (2020, April 21, 2020) Impact of COVID-19 on business valuation. Marks Paneth. Accessed from https://www. markspaneth.com/insights/industry/real-estate/impact-of-covid-19-on-business-valuation

Sahay R, von Allmen UE, Lahreche A, Khera P, Ogawa S, Bazarbash M, Beaton K (2020) The promise of Fintech; financial inclusion in the post COVID-19 era. International Monetary Fund. Working paper No. 20/09. Accessed from https:// www.imf.org/-/media/Files/Publications/DP/2020/English/PFFIEA.ashx

Santaeulalia-Llopis R (2008) Aggregate effects of AIDS on development. Washington University in St. Louis, Unpublished Manuscript

Serrano-Cinca C, Gutierrez-Nieto B, Lopez-Palacios L (2015) Determinants of Default in P2P lending. PLoS ONE 10(10):e0139427

Shen H, Fu M, Pan H, Yu Z, Chen Y (2020) The impact of the COVID-19 pandemic on firm performance. Emerg Mark Financ Trade 56(10):2213-2230

Sindreu J (2020, July 13, 2020) Why Covid-19 won't stop the new Shadow banks. Wall Street J. Accessed from https:// www.wsj.com/articles/why-covid-19-wont-stop-the-new-shadow-banks-11594639940

Skoufias E (2003) Economic crises and natural disasters: Coping strategies and policy implications. World Develop 31(7):1087-1102

Stiglitz JE, Weiss A (1992) Asymmetric information in credit markets and its implications for macro-economics. Oxf Econ Pap 44(4):694-724

Stiller M, ZinkT (2020) Impact of COVID-19 on the European Banking Industry. IDC Perspective, International Data Corporation. Accessed, 27

Tibshirani RJ, Efron B (1993) An introduction to the bootstrap. Monogr Stat Appl Probab 57:1-436

Walthoff-Borm X, Schwienbacher A, Vanacker T (2018) Equity crowdfunding: first resort or last resort? J Business Ventur 33(4):513-533

Wang H, Kou G, Peng Y (2021) Multi-class misclassification cost matrix for credit ratings in peer-to-peer lending. J Oper Res Soc 72(4):923-934. https://doi.org/10.1080/01605682.2019.1705193

Wei Z. Lin M (2017) Market mechanisms in online peer-to-peer lending. Manag Sci 63(12):4236-4257

Wu DD, Olson DL (2020) The effect of COVID-19 on the banking sector. In: Wu DD, Olson DL (eds) Pandemic risk management in operations and finance: modeling the impact of COVID-19. Springer International Publishing, Cham, pp 89-99

Yach D, Stuckler D, Brownell KD (2006) Epidemiologic and economic consequences of the global epidemics of obesity and diabetes. Nat Med 12(1):62-66. https://doi.org/10.1038/nm0106-62

\section{Publisher's Note}

Springer Nature remains neutral with regard to jurisdictional claims in published maps and institutional affiliations. 